\title{
Role of bank credit on local growth: Do politics and crisis matter?
}

\author{
Zeynep Önder ${ }^{1}$, Süheyla Özyıldırım* \\ Bilkent University, Faculty of Business Administrations, Ankara, Turkey
}

\section{A R T I C L E I N F O}

\section{Article history:}

Received 28 September 2011

Received in revised form 13 April 2012

Accepted 3 December 2012

Available online 17 December 2012

\section{JEL classification:}

G21

\section{Keywords:}

State-owned banks

Bank credit

Local growth

Crisis

Election

\begin{abstract}
A B S T R A C T
Although state-owned banks are expected to promote the growth of less-developed regions, especially in developing economies, several cross-country studies report that lending by state banks is associated with the inefficient allocation of credit and low levels of development. Further, state banks have been found to lend to their cronies, especially around elections. In this paper, we study the lending activities of stateowned and private banks during the period 1992-2010 and analyze the relationship between the credit these banks provide and local economic growth in Turkey during crisis periods and in election years. We find that the share of state-owned banks in the credit market in crisis periods and local election years is significantly higher than their share in non-crisis and non-election periods. The per capita real credit that state-owned banks provide during crisis years is found to be positively associated with local growth in all provinces. Our results suggest that although state-owned banks might issue loans for political reasons in election periods, they also seem to play an important role in offsetting the adverse effects of economic shocks, especially in developed provinces.
\end{abstract}

(c) 2012 Elsevier B.V. All rights reserved.

\section{Introduction}

The 2007-2008 financial crisis restarted the long-standing debate on the role of state-owned banks. ${ }^{2}$ Those in support of state-owned banks claim that the banks play an important role in expanding access to financial services for small businesses ${ }^{3}$ or for socially desirable projects that private banks ignore. Despite the theoretical advantages of these banks in broadening access to credit, they are generally regarded as inefficient and vulnerable to political interferences. For example, La Porta et al. (2002) report

\footnotetext{
* Corresponding author. Tel.: +90 312290 1899; fax: +90 3122664958.

E-mail addresses: zonder@bilkent.edu.tr (Z. Önder), suheyla@bilkent.edu.tr (S. Özyıldırım).

1 Tel.: +90 312290 2038; fax: +90 3122664958 .

2 For the most recent discussion about the role of the state-owned banks, see the blog maintained by Demirguc-Kunt (http://blogs.worldbank.org/allaboutfinance/ the-aaf-virtual-debates-join-charles-calomiris-and-franklin-allen-in-a-debate-onstate-owned-banks).

3 Beck and Demirguc-Kunt (2006) highlight that access to and the cost of finance are often ranked as the most constraining features of the business environment by small and medium enterprises (SMEs) and that state-owned banks are expected to solve their financing problems. However, empirical studies have yielded mixed evidence in favor of state-owned banks. For example, Clarke et al. (2005) show that state-owned banks do not necessarily outperform private banks with respect to small business lending in Latin America (Argentina, Chile, Colombia). Beck et al. (2011) document that there is no significant association between greater state ownership of banks and financial access of SMEs across a sample of 38 developing countries. On the other hand, Burgess and Pande (2005) find that a $1 \%$ increase in the number of rural banking locations in India reduces rural poverty by $0.34 \%$.
}

that government ownership of banks could have harmful effects on productivity, economic growth, and the development of financial systems. Micco et al. (2007) document that state-owned banks in developing countries have lower profitability ratios than their private counterparts, and that the gap in their performances increases during election years. Cornett et al. (2010) find that state-owned banks are generally less profitable, have greater credit risk than privately owned banks, and finance the government to a greater degree. Several other studies examine state-owned banks in a single country and present evidence that these banks provide more funding or charge lower interest rates to politically connected firms or individuals (for example, see Sapienza (2004) for Italy, Leuz and Oberholzer-Gee (2006) for Indonesia, Khwaja and Mian (2005) for Pakistan, and Imai (2009) for Japan).

While most of the previous studies report a negative or insignificant effect of state-owned banks on growth, a few recent papers document their positive association with it. Andrianova et al. (2012) examine more than 100 countries during 1995-2007 and show that government ownership of banks was associated with higher long-run growth when controlling for regulatory quality. Similarly, Körner and Schnabel (2009) observe the positive effects of state ownership of banks on the average growth rate of per capita GDP in countries with well-developed financial systems and betterquality political institutions. Önder and Özyıldırım (2010) analyze the effect of state-owned bank credit on local growth in Turkey and show that the loans provided by state-owned banks are associated with higher economic growth in the country's developed provinces. However, this relation is not observed in Turkey's poor provinces, 
which suggests that the role of state-owned banks might depend on the existence of institutional quality even at the micro level.

In general, empirical studies seem to have no standard answer that is valid for all countries and for all situations regarding the role of state-owned banks. Do these banks provide funding for political reasons or to reduce market failures? To contribute this literature, we study the lending behavior of state-owned and private banks during crisis and election years and analyze whether credit provided by these banks in these years affects output growth at the provincial level in Turkey. As highlighted by Levy-Yeyati et al. (2007), private banks might overreact to recessions and amplify the business cycle. Thus, public banks can be used as a crisis resolution vehicle to distribute subsidies to some sectors or regions. Obviously, regions are affected by financial crises with varying severity; developed areas might be hit harder than less-developed areas. ${ }^{4}$ However, to the best of our knowledge, no study in the literature examines how lending by state-owned and private banks varies during crisis periods, whether the loans provided by stateowned banks in these periods have any welfare effect, or whether these effects differ for developed and less-developed regions. Thus, our first aim in this paper is to test whether these banks have any beneficial role during economic slowdowns. ${ }^{5}$

Several empirical studies have examined the lending activities of state-owned banks during election years. For example, Dinç (2005) analyzes lending by banks in 36 countries and reports an increase in lending by state-owned banks during election years, mainly in emerging markets. Similarly, Micco et al. (2007) find that state-owned banks in developing countries increase their loans in election years. Cole (2009) shows that state-owned banks lend more agricultural credit in election years in India but that this extra credit has no significant effect on agricultural revenue or crop yield at the district level. Previous findings suggest that public sources, including state-owned bank funds, are used more for the advancement of governments' ambitions in election periods. However, the important question is whether funds used for political reasons benefit the well being of local people as well. Thus, the second aim of this paper is to provide the answer to this question. By comparing the welfare implications of loans issued by state-owned and private banks on per capita provincial income in election years, we try to understand how a political event might change local prosperity when both state-owned and private banks have access to the same local information.

We study the lending activities of Turkish state-owned and private banks during the period 1992-2010. Turkey is an interesting country in which to analyze the association between lending by these banks and local growth in crisis and election periods. First, over the sample period, the Turkish economy was hit by three crises, and state-owned banks are considered to be among the prime contributors to one of these crises (Steinherr et al., 2004; Alper and Onis, 2004). Second, these banks are the main providers of access to financing in the lagging areas of Turkey.

\footnotetext{
${ }^{4}$ The more modernized areas of Indonesia (Java and urban areas) were hit harder by the Asian crisis than less modernized or agriculture-dominated areas (Brodjonegoro, 2002). After the recent crisis in 2007-2008, disposable income decreased more than $5 \%$ in the northern provinces of Italy but decreased only by about $1.4 \%$ in the southern part (Rizzi and Dallara, 2011).

${ }^{5}$ In the literature, choosing the best way of resolving economic shocks and accelerating economic recovery is still a debated issue. There is evidence that governments may create large fiscal outlays in resolving a banking crisis with the objective to accelerate recovery. For example, Laeven and Valencia (2008) examine 42 crisis episodes during 1970-2007 and present that state-owned banks may be causing large fiscal costs and encourage unproductive risks to be taken at government expense. Although growth and fiscal issues are intertwined regarding the role of state-owned banks, due to data constraints at the provincial level, in this study we only concentrate on the growth issue.
}

Although several state-owned banks have been privatized since the 1980s, three state-owned banks are still available to allocate funds to investment projects in poor regions. Third, control of state-owned banks is very important for political parties, which suggests that they might provide funding for political reasons. ${ }^{6}$ Hence, comparing the economic significance of state-owned and private banks, especially at the provincial level, contributes to the literature on understanding the role of institutional frameworks for regional development, mainly during crisis or election periods.

Our results indicate that the credit market share of state-owned banks in crisis and local election years is significantly higher than their share in non-crisis and non-election years in all provinces, and in less-developed provinces. We find that state-owned and private bank credit per capita alike are positively and significantly associated with the well-being of people in all Turkish provinces. Moreover, credit provided by state-owned banks during crisis years is found to have a significant and positive effect on local growth in all provinces and in developed provinces, but credit granted during election years does not have a significant effect. These results suggest that although state-owned banks might issue loans for political reasons during election periods, they might also play an important role in offsetting the adverse effects of economic shocks, especially in developed regions.

The paper is organized as follows: Section 2 provides information about banking in Turkey. Section 3 summarizes the hypotheses. Section 4 presents the empirical model and the data. Section 5 reports the results and several robustness checks. Section 6 concludes the paper.

\section{The Turkish banking sector}

The Turkish banking sector consists of deposit banks, development and investment banks, and participation banks that operate according to the profit/loss-sharing principle. In 2010, of the 48 banks in the Turkish banking sector, 31 were deposit banks, 13 were development and investment banks, and four were participation banks. The number of state-owned banks was eight in 1990 and three since 2001 (Table 1). As in most other developing countries, state-owned banks in Turkey originated with a clear mandate to finance specific sectors of the economy. ${ }^{7}$ They held $31 \%$ of the total assets of the Turkish banking sector at the end of 2010.

State-owned banks have created a fair amount of price distortion in the Turkish banking sector for years. Their revenues did not reflect real income, as interest earnings on uncollected "duty losses" accrued as income and were reported on the balance sheet as receivables from the treasury. However, they carried out their tasks of extending subsidized credit in the market with short-term financing at higher costs. Eventually, the losses of these banks made them an instability factor in the financial sector (BRSA, 2010). ${ }^{8}$ With the Turkish banking crisis in 2001, the government realized that the current public banking practices could no longer continue. In the second quarter of 2001, the government financially and operationally restructured state banks: preferential credit as part of support programs ceased, and state-owned banks became

\footnotetext{
${ }^{6}$ For example, during the 1997-1999 coalition government period, control of the existing public banks was distributed among three parties in the coalition according to their voting shares.

7 Ziraat Bank was established in 1863 to offer mainly agricultural credit; Emlak Bank was founded in 1927 to provide mortgage loans; Etibank (1935) helped the development of mining and power supplies through credit and Halk Bank (1938) has supplied specialized credit to small businesses and craftsmen.

${ }^{8}$ During the week of February 19, 2001, the two largest state-owned banks, Ziraat Bank and Halk Bank, had losses that amounted to $\$ 2.5$ billion, or about $2 \%$ of the GDP (BRSA, 2010).
} 
Table 1

Some characteristics of deposit banks in Turkey, 1990-2010.

\begin{tabular}{|c|c|c|c|c|c|c|c|c|c|}
\hline & \multicolumn{3}{|c|}{ State-owned banks } & \multicolumn{6}{|c|}{ Private banks } \\
\hline & \multirow[t]{2}{*}{1990} & \multirow[t]{2}{*}{2010} & \multirow[t]{2}{*}{ Mean $^{a}$} & \multicolumn{3}{|c|}{ Domestic banks } & \multicolumn{3}{|c|}{ Foreign banks } \\
\hline & & & & 1990 & 2010 & Mean & 1990 & 2010 & Mean \\
\hline Number of banks & 8 & 3 & 4 & 25 & 11 & 24 & 23 & 17 & 17 \\
\hline Number of branches & 2975 & 2744 & 2623 & 3455 & 4582 & 3684 & 113 & 2096 & 546 \\
\hline Number of employees & 80,825 & 47,235 & 59,249 & 68,145 & 82,270 & 72,103 & 3012 & 42,013 & 12,106 \\
\hline Branch/bank & 372 & 915 & 655 & 138 & 417 & 191 & 5 & 123 & 33 \\
\hline Employee/branch & 27.2 & 17.2 & 22.2 & 19.7 & 18.3 & 19.6 & 26.7 & 20.0 & 26.9 \\
\hline Total assets (USD million) & 25,917 & 193,850 & 60,805 & 25,156 & 322,919 & 110,177 & 2011 & 88,171 & 20,003 \\
\hline Total loans (USD million) & 12,340 & 95,344 & 20,305 & 10,809 & 170,322 & 50,005 & 969 & 52,956 & 11,134 \\
\hline Total deposits (USD million) & 15,797 & 148,465 & 45,530 & 11,337 & 200,329 & 69,252 & 776 & 50,956 & 11,497 \\
\hline Deposits/assets (\%) & 61.0 & 76.6 & 72.9 & 63.6 & 72.1 & 63.9 & 57.8 & 57.8 & 48.2 \\
\hline \multicolumn{10}{|l|}{ Soundness measures (\%) } \\
\hline Non-performing loans/loans ${ }^{b}$ & 1.7 & 3.3 & 11.4 & 0.5 & 3.3 & 5.6 & 0.3 & 6.1 & 3.9 \\
\hline Capital/total assets & 8.2 & 9.9 & 7.7 & 11.5 & 13.4 & 11.8 & 11.1 & 13.6 & 14.9 \\
\hline Return on assets & 2.2 & 2.3 & 1.5 & 3.5 & 2.4 & 2.8 & 3.6 & 1.4 & 4.7 \\
\hline Liquid assets/total assets & 29.9 & 30.2 & 42.6 & 39.0 & 34.1 & 42.3 & 42.5 & 33.9 & 49.7 \\
\hline Loans/total assets & 47.6 & 49.2 & 34.2 & 43.0 & 52.7 & 41.4 & 48.2 & 60.1 & 39.0 \\
\hline
\end{tabular}

Source: Turkish Banking Association.

a Mean columns report average values for the period 1990-2010.

b Loans include total loans and receivables.

subject to the same regulations and supervisions as private banks. ${ }^{9}$ As a result, they have become increasingly "prudent" in accepting bad loans and waiving appropriate provisions, and are creating more transparent balance sheets, and have more reasonable amounts for loan portfolios. Their non-performing loans-to-gross loans ratio decreased from $18.6 \%$ in 2001 to $3.8 \%$ in 2010; their total loans-to-total assets ratio and their liquid assets-to-total assets ratio increased to $49.2 \%$ and $30.2 \%$, respectively, in 2010 (Table 1 ).

Privately owned banks have dominated the Turkish banking sector since the early 1990s. Some private domestic banks are large-scale, providing diverse banking services through their nation-wide branch networks. Some privately owned banks are small- or mid-sized, concentrating their activities in larger centres and engaging mainly in wholesale banking. During the $1980 \mathrm{~s}$ and 1990s, the government's borrowing had absorbed an important portion of the loanable funds in the economy, leaving little for the private sector. However, the decline in government borrowing, inflation, and real interest rates after the banking crisis in 2001 allowed private banks to concentrate more on lending to the private sector. The market shares of private domestic banks in the credit market increased from 39.5\% in 1990 to $53.5 \%$ in $2010 .{ }^{10}$

Foreign bank entry into Turkey began with its financial liberalization in the 1980s. Of the 43 banks in 1980, only four were foreign. Currently, there are more foreign commercial banks operating in Turkey than domestic banks (Table 1). However, their share was very small until recently. The asset share of foreign banks was below 5\% in 2005 and increased to $14.6 \%$ in 2010. Similarly, their share in the credit market increased after 2005 and became $16.6 \%$ in 2010. By the acquisition of four domestically owned private banks, the network of foreign banks increased more than fivefold during the period 2005-2010.

As of 2010 , on average, deposits constituted $62 \%$ of the total resources in the Turkish banking sector. This ratio is over 70\% for state-owned and private domestic banks. Asset quality, that

\footnotetext{
${ }^{9}$ Until a new autonomous agency, the Banking Regulation and Supervision Agency (BRSA) was established in September 2001 to regulate the banking sector, banking supervision had been split between the Central Bank (off-site) and the Treasury (on-site)

10 In 2010, commercial banks issued $96.8 \%$ of all loans. The remaining $3.2 \%$ belonged to development and investment banks.
}

is, non-performing loans as a fraction of gross loans, and the capitalization ratio of state-owned and domestic private banks improved considerably during the last decade (Table 1). Yet, due to increase in competition in the sector, especially with the penetration of foreign banks, the profitability of private domestic banks has declined in recent years.

Compared to the size of the economy, the Turkish banking sector is still relatively small. The ratio of total assets of all banks to GDP was 29\% in 1990 and increased to $91 \%$ at the end of 2010 . The credit/GDP ratio and the deposits/GDP ratio were only $15 \%$ in 1990 and increased to $43 \%$ and $54 \%$, respectively in $2010 .{ }^{11}$ These ratios are far below the EU average but closer to the ratios in the transition economies of the EU.

The Turkish banking industry is dominated by seven large banks: three state-owned and four private domestic banks. They held $78.2 \%$ of the sector assets in December 2010. The share of the five largest banks - a common indicator of concentration - stands at $62.9 \%$ and indicates a fair level of competition in the sector.

Bank branches are one of the fundamental channels for providing banking services in Turkey. There are 9422 branches of 31 deposit banks as of December 2010 and 29\% of these branches belong to three state-owned banks. The seven largest banks have branches in all of Turkey's 81 provinces. At the provincial level, branch density is low compared to developed countries but almost the same as the world average (International Finance Corporation, 2010). There were 13 branches for every 100,000 persons in 2010.

\section{Hypotheses}

In this paper, we examine the lending activities of state-owned and private banks in crisis years and in general (i.e., parliamentary) and local election years. First, we analyze whether the shares of state-owned and private banks in credit markets are different in crisis and non-crisis years and in election and non-election years. Then, we study how the relationship between credit provided by banks with different ownership and local economic growth changes in these years. We conduct the analyses for all provinces as well as for a subsample of developed and less-developed provinces.

11 GDP in current prices was 150,676 million USD in 1990 and became 735,264 million USD in 2010 . 


\subsection{The shares of state-owned and private banks in the credit market}

\subsubsection{Bank credit during crisis years}

During periods of economic crisis, banks reduce their lending activities by investing in securities, especially government securities (Bernanke and Lown, 1991). However, some studies show that the lending activities of state-owned banks are less responsive to macroeconomic shocks than those of private banks (see, for example, Detragiache and Gupta (2006) for Malaysia and Micco and Panizza (2006) for developing countries). Micco and Panizza (2006) list four reasons for the insignificant change in the behavior of state-owned banks in crisis years: (i) state-owned banks try to stabilize the credit market as part of government policy, (ii) they have excess loanable funds because depositors prefer to channel their savings to these banks as safe havens during recessions, (iii) the managers of these banks might be slow to react to shocks, and (iv) politicians might influence the lending behavior to increase their probability of re-election. In this paper, we postulate that state-owned banks do not react as much as private banks in economic crisis periods and examine this hypothesis at the provincial level by using a simple market share measure.

\subsubsection{Bank credit during election years}

Elections are one of the most studied political events in the banking literature, and several studies have documented that stateowned banks change their lending behavior during election years. Dinç (2005) examines the behavior of the ten largest banks in 17 developed and 19 developing countries and finds that state-owned banks (relative to private banks) increase their lending in election years only in developing countries. Micco and Panizza (2006) also observe lending during election years but find no significant relation between loan growth and political lending in industrial or developing countries. Later, Micco et al. (2007) find that stateowned banks perform worse than private banks and that the disparity between them widens during election years, especially in developing countries. ${ }^{12}$ Baum et al. (2010) examine the effects of general elections on the Turkish banking system between 1963 and 2007 and observe no significant difference between lending behavior of state-owned and other types of banks during parliamentary elections. Jackowicza et al. (2012) find that although state-owned banks charge significantly lower interest rates on loans in the years of parliamentary elections in Central European countries, their loan volume does not change significantly.

In this paper, we examine local and general elections. We hypothesize that state-owned banks' share of the credit market in election periods is significantly greater than their share in nonelection periods. Since 1986, provincial municipalities have been allowed by law to borrow from all types of commercial banks (i.e., state-owned, private, or foreign banks). Hence, it would not be surprising to observe a larger provision by private banks in the credit market in election years; however, their share is expected to decline in these periods.

\subsubsection{Bank credit in less-developed and developed provinces}

Increasing growth and reducing economic disparity between regions are major challenges for incumbent governments in many developing economies. The Turkish government has been classifying certain provinces as "priority provinces for development"

\footnotetext{
12 They define 'election years' as years with presidential elections in countries with a presidential system and legislative elections in countries with parliamentary systems. Their sample comprises 179 countries.
}

since 1968 to provide incentives and subsidies to improve growth in these provinces. The number of provinces included in this list has increased over time and now stands at 50 out of 81 provinces. In this paper, we use this classification to examine whether state-owned banks behave differently in developed (nonpriority) and less-developed (priority) provinces in crisis and election years.

In Turkey, Önder and Özyıldırım (2010) find that credit provided by state-owned banks has a negative or insignificant association with local growth in "priority" provinces but a positive association with growth in developed provinces for the period 1992-2000. In another study, they show that credit provided by state-owned banks is associated with local growth in "priority" provinces if they are politically connected with the government (Önder and Özyıldırım, 2011). Based on these findings, we expect that state-owned banks will behave differently in developed and lessdeveloped provinces in the crisis and election years.

\subsection{The relationship between bank credit and local growth}

After examining whether the credit market share of Turkish state-owned banks is higher in election and crisis years, we test whether the per capita credit they provide during these periods is positively associated with per capita GDP growth rate in all provinces regardless of their development level, controlling for other factors that might affect growth rate. Although previous empirical studies show that generally the management of stateowned banks has political incentives in allocating credit regardless of the state of the economy (see for example, Sapienza, 2004; Imai, 2009), we do not have an a priori expectation about the contribution of these banks on economic growth in normal times. However, we may observe a positive association between credit provided by state-owned banks and provincial growth during crisis periods if state-owned banks fill financial gaps possibly created by private banks and finance economically desirable projects that are ignored by private banks. Nevertheless, governments may also make politically motivated lending decisions during crisis periods to implement their discretionary policies (see Bongini et al. (2001) during the 1997-1999 East Asian crisis and McQuerry (2001) during the 1994 Brazilian banking crisis). If state-owned banks are more lenient and less prudent during crisis periods, no association with growth may be observed.

Similarly, we may see loan expansion by Turkish state-owned banks during election periods, but lenient lending behavior and marginally granted credit may increase default rates in the wake of elections. Hence, like normal periods, we have no a priori expectation on the relationship between local growth and loans provided by state-owned and private banks during periods of increased uncertainty and asymmetric information.

\section{Empirical model and data}

\subsection{The model}

To examine the relationship between bank credit and economic growth at the provincial level over the period 1992-2010, we estimate the following fixed-effects model:

$$
\begin{aligned}
Y_{i t}= & \beta_{0}+\beta_{1} \text { Bank Credit }_{i t}+\beta_{2} \text { Public Expenditure }_{i t} \\
& +\beta_{3} \text { Urbanization }_{i t}+\beta_{4} \text { Schooling }_{i t}+\beta_{5} G D P_{i t-1}+\beta_{6} D_{\text {Crisis }} \\
& +\beta_{7} D_{\text {Election }}+\beta_{8} D_{j} \times \text { Bank Credit }_{i t}+v_{i}+\epsilon_{i t}
\end{aligned}
$$

where $Y_{i t}$ is the growth rate of real GDP per capita in province $i$ at time $t$. Bank Credit ${ }_{i t}$ denotes either per capita state-owned bank 
credit or per capita private bank credit provided in province $i$ at time $t^{13}$

We try to control for other factors that may affect a province's per capita income growth rate. The control variables are public expenditures per capita (Public Expenditure), the share of urban population (Urbanization), a measure of human capital (Schooling), and the lagged per capita real output $\left(G D P_{t-1}\right)$. We expect the coefficient on public expenditures and urbanization to be positive and the coefficient on income level to be negative. Human capital represents the number of high-school students per high-school teacher, and the expectation is that this variable has a positive relation to provincial growth rate. $D_{\text {Crisis }}$ and $D_{\text {Election }}$ are dummy variables indicating crisis and election years respectively. $v$ is a vector representing provincial fixed-effects.

We examine how the relationship between bank credit and growth changes in crisis or election years by the interaction variables $\left(D_{j} \times\right.$ Bank Credit $_{i t}$, where $j=$ Crisis, Election (Local or General)). $\beta_{8}$ measures the change in the coefficient on per capita credit provided by either state-owned or private banks in crisis or election years.

Turkey experienced three major economic crises during the sample period. The first crisis was of short-duration, in 1994, and was a currency crash and a banking crisis. Three private banks failed. Fiscal fundamentals deteriorated significantly. The huge domestic credit expansion to the public sector eventually caused drastic depreciation of the Turkish Lira (TL) and resulted in the loss of foreign assets of the Central Bank of the Republic of Turkey (CBRT). After an output loss of $6.1 \%$ in 1994 , output recovery was rapid. The economy grew 7.5\% and 8\% in 1995 and 1996, respectively. The second crisis had a long-duration, spreading over three years (1999-2001). In 1999, there was another currency crash and through 2000 and 2001 another banking crisis. The real GDP growth rate was $-3.37 \%$ in $1999,6.77 \%$ in 2000 , and $-5.67 \%$ in 2001 . Turkey implemented an IMF-supported program at the beginning of 2000, which succeeded to some extent, reversing the negative trend in GDP for that year. However, rising current account deficits, real appreciation of the TL, and the fragility of state-owned and private banks were considered the cause of the severe financial crisis in 2001 , so the program ultimately failed. The effects of this second crisis on the banking sector were more severe than those of the first one. Seventeen banks failed over three years. We consider the global crisis periods of 2008 and 2009 as Turkey's third crisis period because it was one of the hardest-hit countries. The recession of 2008-2009 led to a massive collapse in exports and the subsequent contraction in GDP of $14.7 \%$ during the first quarter of 2009 (Alp and Elekdag, 2011). By the second quarter of 2009 , the economy had quickly rebounded. Financial markets seem to be resilient in contrast to previous crises. Thus, in the empirical model, the dummy variable for crisis, $D_{\text {Crisis }}$, takes a value of one in 1994, 1999, 2000, 2001, 2008, and 2009 and 0 otherwise.

During the sample period, there were four local elections, in $1994,1999,2004$, and 2009. Hence, the dummy variable $D_{\text {LElection }}$ defines local election periods and equals one in these years and 0 otherwise. In the analysis of general elections, the dummy variable, $D_{\text {GElection }}$ takes a value of one in the general election years (1995, 1999, 2002, and 2007) and 0 otherwise. ${ }^{14}$

When examining the impact of a crisis, we control for local election years rather than general election years because the

\footnotetext{
13 Because of the multicollinearity problem, we did not jointly estimate per capita credit issued by state-owned and private banks.

${ }^{14}$ In order to differentiate the pure effect of crisis or election years, if two events concurrently occur in the same year, then that year is excluded from the estimations.
}

estimations are done at the provincial rather than national level. Moreover, political parties seem to view local elections as more crucial in expanding their electoral popularity in the national political arena because of the large concentrations of voters in urban areas. For example, Incioglu (2002) argues that in Turkey “... [t]he growing importance of local elections, especially those concerning municipal administrations, is further underscored by the fact that the mayors of large metropolises have become more influential in national politics than many legislators serving in the parliament."

We divide the provinces into developed and less-developed according to the list of priority provinces that Council of Ministers determines annually. The model is estimated for these two subsamples of provinces. We expect that state-owned bank credit has a positive effect on local growth in election years especially in the less-developed provinces because the previous findings indicate that state-owned banks do much better in less-developed, politically connected provinces. Moreover, we expect that an economic shock will have a greater impact on developed provinces. Hence, the extra credit that a state-owned bank provides during crisis years is expected to have more of an effect on the growth rate in developed provinces.

In the growth literature, credit is usually treated as an endogenous variable. First we test whether state-owned and private bank credit is endogenous or not. According to the results of the Hausman test, we cannot reject the hypothesis that state-owned bank credit is exogenous but we can reject the hypothesis that private bank credit is exogenous. Therefore, we use the OLS estimation in our analysis on state-owned bank credit. For estimations with private bank credit, we identify the share of private bank branches located in that province as an appropriate instrumental variable (IV) ${ }^{15}$ and estimate our models accordingly. ${ }^{16}$

\subsection{Data}

We constructed an unbalanced panel data set $^{17}$ by employing annual data on credit provided by state-owned and private banks in the provinces between 1992 and 2010. All data on bank credit come from the CBRT. ${ }^{18}$ Provincial public expenditures come from the Turkish Ministry of Finance and the other variables come from the Turkish Statistics Institute.

Table 2 shows the mean values of bank credit and provincial characteristics for the whole sample and for the sub-samples that comprise local and general elections and non-election years, crisis and non-crisis years, and less-developed and developed provinces. During the sample period, the average growth rate of per capita

\footnotetext{
15 Although dynamic GMM is widely used in the growth literature (for example, see Beck et al., 2000; Levine et al., 2000), we rejected the hypotheses of over-identification restrictions with the Sargan test and the second-order serial correlation of error terms with the Arellano-Bond test. The estimates would not be robust using the dynamic GMM approach; therefore, we used the OLS and IV methods.

16 The correlation coefficient between the provincial growth rate and the share of private bank branches is -0.048 whereas the correlation coefficient between credit issued by private banks and the share of private bank branches is 0.762 .

17 The number of provinces changed during the sample period from 67 in 1992 to 81 in 2000 . Fourteen new provinces were established from districts of existing provinces. In the estimations, former provinces were excluded from the sample in the year when new provinces were delineated from them because of the artificial decline in GDP level of the former provinces in that year.

18 In the empirical analysis, we use only cash loans provided by the corresponding banks as credit. In addition to cash loans, banks can issue non-cash loans, such as letters of guarantee, acceptances, and credit.

The CBRT classifies banks as state-owned or privately owned. In this grouping, foreign and participation banks are considered private banks when providing credit data at the province level. Because of data availability, we use the CBRT's classifications.
} 
Table 2

Descriptive statistics of variables.

\begin{tabular}{|c|c|c|c|c|c|c|c|c|c|}
\hline & \multirow[t]{3}{*}{ All } & \multicolumn{2}{|l|}{ Crisis years } & \multicolumn{4}{|c|}{ Election years } & \multicolumn{2}{|l|}{ Provinces } \\
\hline & & \multirow[t]{2}{*}{ No } & \multirow[t]{2}{*}{ Yes } & \multicolumn{2}{|l|}{ Local } & \multicolumn{2}{|l|}{ General } & \multirow[t]{2}{*}{ Developed } & \multirow[t]{2}{*}{ Less developed } \\
\hline & & & & No & Yes & No & Yes & & \\
\hline Per capita real GDP growth rate (\%) & $\begin{array}{l}2.89 \\
(7.28)\end{array}$ & $\begin{array}{l}5.86 \\
(5.38)\end{array}$ & $\begin{array}{l}-3.42 \\
(6.75)\end{array}$ & $\begin{array}{l}3.85 \\
(6.60)\end{array}$ & $\begin{array}{l}-0.66 \\
(8.49)\end{array}$ & $\begin{array}{l}2.91 \\
(7.33)\end{array}$ & $\begin{array}{l}2.83 \\
(7.09)\end{array}$ & $\begin{array}{l}2.44 \\
(6.70)\end{array}$ & $\begin{array}{l}3.17 \\
(7.60)\end{array}$ \\
\hline \multicolumn{10}{|l|}{ Bank credit per capita (TL) } \\
\hline State-owned banks & $\begin{array}{l}502.43 \\
(656.37)\end{array}$ & $\begin{array}{l}469.79 \\
(634.6)\end{array}$ & $\begin{array}{l}571.75 \\
(695.98)\end{array}$ & $\begin{array}{l}493.31 \\
(657.4)\end{array}$ & $\begin{array}{l}536.14 \\
(652.46)\end{array}$ & $\begin{array}{l}517.47 \\
(659.49)\end{array}$ & $\begin{array}{l}446.87 \\
(642.69)\end{array}$ & $\begin{array}{l}645.73 \\
(628.84)\end{array}$ & $\begin{array}{l}414.44 \\
(657.74)\end{array}$ \\
\hline Private banks & $\begin{array}{l}795.54 \\
(1525.51)\end{array}$ & $\begin{array}{l}775.67 \\
(1474.45)\end{array}$ & $\begin{array}{l}837.74 \\
(1629.43)\end{array}$ & $\begin{array}{l}802.5 \\
(1540.59)\end{array}$ & $\begin{array}{l}769.86 \\
(1470.53)\end{array}$ & $\begin{array}{l}820.87 \\
(1553.12)\end{array}$ & $\begin{array}{l}701.99 \\
(1417.22)\end{array}$ & $\begin{array}{l}1531.39 \\
(2207.92)\end{array}$ & $\begin{array}{l}343.7 \\
(478.63)\end{array}$ \\
\hline Public expenditures per capita (TL) & $\begin{array}{l}134.34 \\
(154.98)\end{array}$ & $\begin{array}{l}138.11 \\
(163.42)\end{array}$ & $\begin{array}{l}126.31 \\
(135.13)\end{array}$ & $\begin{array}{l}136.42 \\
(158.25)\end{array}$ & $\begin{array}{l}126.65 \\
(142.23)\end{array}$ & $\begin{array}{l}141.48 \\
(160.62)\end{array}$ & $\begin{array}{l}107.92 \\
(128.9)\end{array}$ & $\begin{array}{l}143.1 \\
(204.38)\end{array}$ & $\begin{array}{l}128.95 \\
(114.28)\end{array}$ \\
\hline Urbanization (\%) & $\begin{array}{l}56.69 \\
(13.32)\end{array}$ & $\begin{array}{l}56.33 \\
(13.17)\end{array}$ & $\begin{array}{l}57.44 \\
(13.62)\end{array}$ & $\begin{array}{l}56.50 \\
(13.22)\end{array}$ & $\begin{array}{l}57.35 \\
(13.66)\end{array}$ & $\begin{array}{l}56.72 \\
(13.45)\end{array}$ & $\begin{array}{l}56.56 \\
(12.84)\end{array}$ & $\begin{array}{l}62.98 \\
(14.83)\end{array}$ & $\begin{array}{l}52.81 \\
(10.58)\end{array}$ \\
\hline \multicolumn{10}{|l|}{ Schooling } \\
\hline Students per teacher & $\begin{array}{l}17.56 \\
(5.31)\end{array}$ & $\begin{array}{l}17.48 \\
(5.44)\end{array}$ & $\begin{array}{l}17.71 \\
(5.02)\end{array}$ & $\begin{array}{l}17.57 \\
(5.45)\end{array}$ & $\begin{array}{l}17.49 \\
(4.76)\end{array}$ & $\begin{array}{l}17.51 \\
(5.27)\end{array}$ & $\begin{array}{l}17.72 \\
(5.42)\end{array}$ & $\begin{array}{l}16.70 \\
(4.08)\end{array}$ & $\begin{array}{l}18.11 \\
(5.90)\end{array}$ \\
\hline$D_{\text {Crisis }}(\%)$ & 31.99 & 0.00 & 100.00 & 20.49 & 74.53 & 33.84 & 25.16 & 31.81 & 32.11 \\
\hline$D_{\text {LElections }}(\%)$ & 21.29 & 7.97 & 49.58 & 0.00 & 100.00 & 20.24 & 25.16 & 21.27 & 21.30 \\
\hline$D_{\text {GElections }}(\%)$ & 21.29 & 23.43 & 16.74 & 20.24 & 25.16 & 0.00 & 100.00 & 21.27 & 21.30 \\
\hline
\end{tabular}

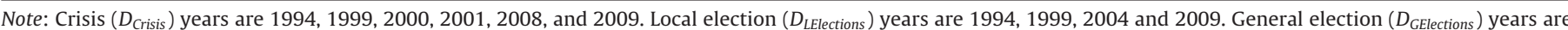
$1995,1999,2002$, and 2007. Standard deviations are reported in parentheses. Monetary values are expressed in terms of 2010 prices.

provincial GDP was $2.89 \%$. It changes significantly in the subsamples. For example, it was $-0.66 \%$ during local election years and $-3.42 \%$ during crisis years. Less-developed provinces had a higher growth rate than developed provinces during the period $1992-2010$ (3.17\% versus $2.44 \%$ ). Part of this growth rate can be explained by the people migrating from less-developed to developed provinces.

On average, state-owned banks provided $502.43 \mathrm{TL}^{19}$ per capita per year in a province, whereas private banks provided 795.54 TL. Fig. 1 shows how per capita provincial bank credit changed through the sample period. In terms of 2010 values, state-owned and private banks seem to provide almost the same amount of credit per capita during 1992-2001. After 2001, the amount of credit per capita from both types of banks increases exponentially. Moreover, private banks have a higher growth rate than state-owned banks. The high average in crisis years, as reported in Table 2, can be explained by the increase in the per capita bank credit in the later years that coincided with the crisis.

Table 2 shows that both types of bank credit per capita are higher in developed provinces. Private banks provide on average almost 4.5 times more credit per capita in developed provinces than in lessdeveloped provinces. The average per capita public expenditures in a province is almost one-third of the mean of per capita credit provided by state-owned banks. Moreover, average per capita public expenditures are lower in crisis and election periods. Considering the nature of public expenditures (infrastructure, health, education, civil servant salaries, and transfer payments), the trend during crisis periods is logical; however, a lower mean value during election periods is unexpected.

\section{Empirical results}

\subsection{State-owned and private banks' credit market shares}

To test the hypotheses about the equality of state-owned and private bank lending activities in different years and in different

\footnotetext{
19 All monetary values are expressed as of their values at the end of 2010. At that time, the exchange rate was $1 \mathrm{USD}=1.54 \mathrm{TL}$.
}

provinces, we calculate the credit market shares of both bank types in each province and in each year. Table 3 shows the mean value of the market shares of each type of bank in alternative years and provinces as well as the $t$-statistics that test the equality of these mean values. The results show that at the provincial level, stateowned banks have a significantly higher market share in crisis years $(54.3 \%)$ than in non-crisis periods $(47.5 \%){ }^{20}$ On the other hand, the market share of private banks in the credit market is significantly lower in crisis years (45.7\%) than in non-crisis years (52.2\%). The CBRT (2010) also documents the assurance of state-owned bank lending in the recent crisis.

We observe similar behavior for state-owned banks in local election years. We find that at the provincial level, these banks have a significantly higher market share in local election years $(52.2 \%$ versus $49.0 \%$ ). On the other hand, private banks have a significantly lower market share in local election years than in non-election years. Although state-owned banks have a higher market share in general election years, no significant difference exists between general election years and non-election years. This finding supports the results of Baum et al. (2010), which hold that state-owned banks in Turkey do not change their lending activity during general election years.

When we compare the credit market shares of banks in different provinces, state-owned banks have a significantly higher share in credit markets of less-developed provinces than in those of developed provinces. The average share of state-owned banks increases to $62.9 \%$ in less-developed provinces and decreases to $40.4 \%$ in developed provinces in crisis years. Their share is around $60 \%$ in local and general election years alike. Private banks have a significantly lower market share in crisis and local election years. The difference in market share is significant in all provinces and in developed provinces when comparing local election years to non-election years.

Knowing that state-owned banks have a significantly higher share of the credit market during local election and crisis years,

\footnotetext{
${ }^{20}$ Although the average market shares of public and private banks are around $50 \%$, it changed significantly over time. For example, in 1992, the share of state-owned banks was $74.0 \%$ and declined to $47.1 \%$ in 2010 .
} 


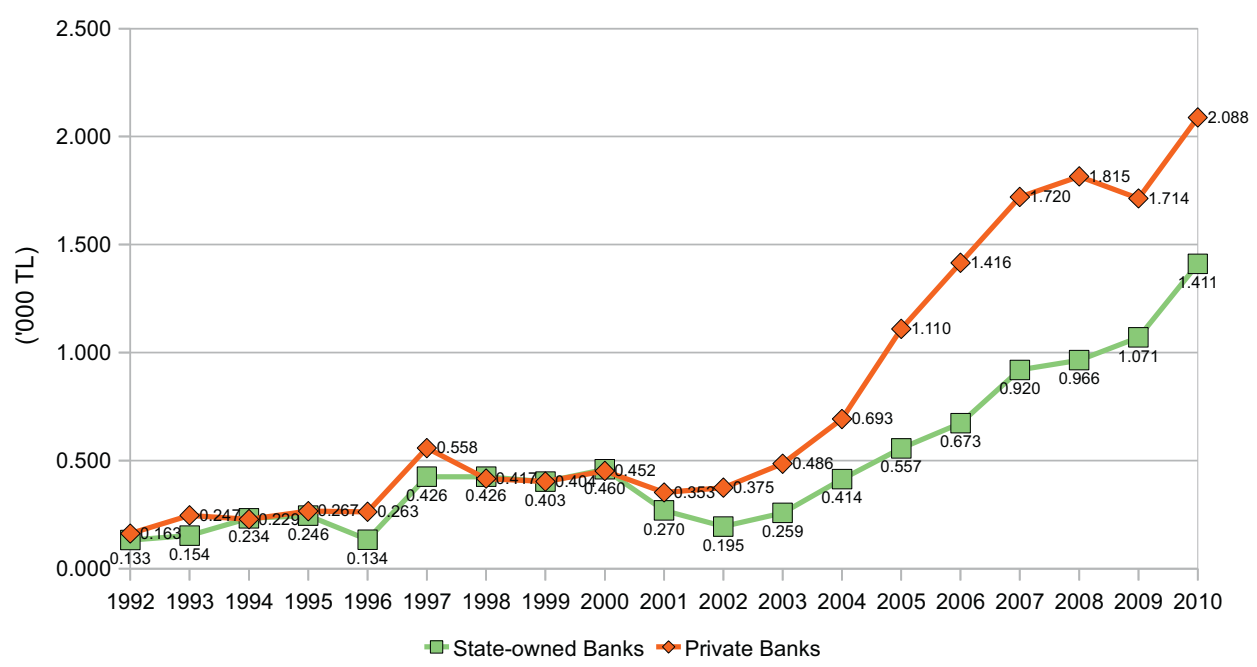

Fig. 1. Provincial real credit per capita, 1992-2010.

Table 3

Means and standard deviations of credit market shares of State-owned and private banks in Turkish provinces in different periods and $t$-statistics for equality of means.

\begin{tabular}{|c|c|c|c|c|c|c|c|c|c|}
\hline & \multicolumn{3}{|l|}{ All } & \multicolumn{3}{|c|}{ Less-developed provinces } & \multicolumn{3}{|l|}{ Developed provinces } \\
\hline & State-owned banks & Private banks & $N$ & State-owned banks & Private banks & $N$ & State-owned banks & Private banks & $N$ \\
\hline \multicolumn{10}{|l|}{ Crisis } \\
\hline No & $\begin{array}{l}47.52 \% \\
(22.76)\end{array}$ & $\begin{array}{l}52.17 \% \\
(22.64)\end{array}$ & 1021 & $\begin{array}{l}55.14 \% \\
(22.16)\end{array}$ & $\begin{array}{l}44.35 \% \\
(21.81)\end{array}$ & 632 & $\begin{array}{l}35.15 \% \\
(17.74)\end{array}$ & $\begin{array}{l}64.88 \% \\
(17.69)\end{array}$ & 389 \\
\hline Yes & $\begin{array}{l}54.31 \% \\
(22.89)\end{array}$ & $\begin{array}{l}45.70 \% \\
(22.93)\end{array}$ & 479 & $\begin{array}{l}62.89 \% \\
(20.50)\end{array}$ & $\begin{array}{l}37.13 \% \\
(20.57)\end{array}$ & 296 & $\begin{array}{l}40.41 \% \\
(19.53)\end{array}$ & $\begin{array}{l}69.56 \% \\
(19.56)\end{array}$ & 183 \\
\hline$t$-Stat & $-5.37^{* * *}$ & $5.14^{* * *}$ & & $-5.08^{* * *}$ & $4.79^{* * *}$ & & $-3.21^{* * *}$ & $3.24^{* * *}$ & \\
\hline \multicolumn{10}{|c|}{ Local election } \\
\hline No & $\begin{array}{l}49.01 \% \\
(23.04)\end{array}$ & $\begin{array}{l}50.73 \% \\
(22.92)\end{array}$ & 1182 & $\begin{array}{l}56.93 \% \\
(22.02)\end{array}$ & $\begin{array}{l}42.63 \% \\
(21.68)\end{array}$ & 732 & $\begin{array}{l}36.12 \% \\
(18.37)\end{array}$ & $\begin{array}{l}63.91 \% \\
(18.33)\end{array}$ & 450 \\
\hline Yes & $\begin{array}{l}52.22 \% \\
(22.73)\end{array}$ & $\begin{array}{l}47.79 \% \\
(22.84)\end{array}$ & 318 & $\begin{array}{l}60.16 \% \\
(21.48)\end{array}$ & $\begin{array}{l}39.87 \% \\
(21.58)\end{array}$ & 196 & $\begin{array}{l}39.47 \% \\
(18.71)\end{array}$ & $\begin{array}{l}60.50 \% \\
(18.76)\end{array}$ & 122 \\
\hline$t$-Stat & $-2.21^{* *}$ & $2.04^{* *}$ & & $-1.83^{*}$ & 1.58 & & $-1.78^{*}$ & $1.81^{*}$ & \\
\hline \multicolumn{10}{|c|}{ General election } \\
\hline No & $\begin{array}{l}49.44 \% \\
(22.77)\end{array}$ & $\begin{array}{l}50.30 \% \\
(22.65)\end{array}$ & 1181 & $\begin{array}{l}57.11 \% \\
(21.86)\end{array}$ & $\begin{array}{l}42.46 \% \\
(21.52)\end{array}$ & 732 & $\begin{array}{l}36.93 \% \\
(18.24)\end{array}$ & $\begin{array}{l}63.08 \% \\
(18.22)\end{array}$ & 449 \\
\hline Yes & $\begin{array}{l}50.61 \% \\
(23.91)\end{array}$ & $\begin{array}{l}49.39 \% \\
(23.95)\end{array}$ & 319 & $\begin{array}{l}59.49 \% \\
(22.15)\end{array}$ & $\begin{array}{l}40.50 \% \\
(22.24)\end{array}$ & 196 & $\begin{array}{l}36.46 \% \\
(19.41)\end{array}$ & $\begin{array}{l}63.54 \% \\
(19.39)\end{array}$ & 123 \\
\hline t-Stat & -0.81 & 0.63 & & -1.35 & 1.12 & & 0.25 & -0.25 & \\
\hline
\end{tabular}

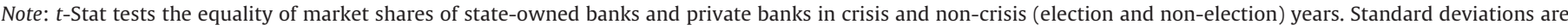

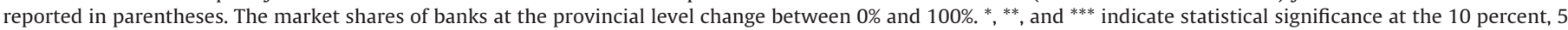
percent and 1 percent levels, respectively.

we further examine whether this credit has a positive association with individuals' well-being at the provincial level.

\subsection{Bank credit and local growth}

Table 4 reports the results of the fixed-effects model without interaction variables. The basic model with state-owned bank credit explains $33.2 \%$ of the variability in the per capita GDP growth rates in the Turkish provinces and the model with private bank credit explains $33.7 \%$ of the variability. The provincial fixed-effects are found to be significant. Therefore, they are included in all estimations.

Per capita state-owned and private bank credit are both found to be significantly and positively associated with the provincial per capita growth rate of real GDP, controlling for other factors that might affect provincial growth, such as public expenditures, urbanization, schooling, and initial income level of a province. Interestingly, the coefficient on per capita state-owned bank credit is significant in developed provinces, whereas the coefficient on per capita private bank credit is significant in less-developed provinces.
However, both types of bank credit have a positive and significant effect on local growth in all provinces regardless of their development level. This result is slightly different from previous studies that examine the role of state-owned banks in Turkey (Önder and Özyıldırım, 2010; Önder and Özyıldırım, 2011), which find an insignificant coefficient on per capita credit for all provinces. Different from those studies, this study covers a period when an independent bank regulatory agency exists in Turkey. These findings seem to support the requirements offered by Guidotti et al. (2004) that regulatory institutions should be independent from political influences for the reliable operation of the financial system.

The positive coefficient found on state-owned bank credit even in developed provinces seems to support the development view explanation of government ownership of banks. ${ }^{21}$ However, it is

21 Proponents of the development view claim that public banks cure financial market failures and therefore enhance social welfare or stimulate growth (see, e.g., Atkinson and Stiglitz, 1980). 
Table 4

Fixed-effects model - bank credit and local growth.

\begin{tabular}{|c|c|c|c|c|c|c|}
\hline & \multicolumn{3}{|c|}{ State-owned banks } & \multicolumn{3}{|l|}{ Private banks } \\
\hline & All provinces & Less-developed & Developed & All provinces & Less-developed & Developed \\
\hline \multirow[t]{2}{*}{ Bank Credit $\left(\beta_{1}\right)$} & $0.0089^{* *}$ & 0.0049 & $0.0126^{* *}$ & $0.0079^{*}$ & $0.0224^{* * *}$ & 0.0027 \\
\hline & $(0.0038)$ & $(0.0051)$ & $(0.0054)$ & $(0.0044)$ & $(0.0075)$ & $(0.0051)$ \\
\hline \multirow{2}{*}{ Public Expenditures $\left(\beta_{2}\right)$} & $0.0643^{* * *}$ & $0.0921^{* * *}$ & 0.0099 & $0.0777^{* * *}$ & $0.1087^{* * *}$ & 0.0150 \\
\hline & $(0.0188)$ & $(0.0271)$ & $(0.0249)$ & $(0.0192)$ & $(0.0268)$ & $(0.0264)$ \\
\hline \multirow{2}{*}{ Urbanization $\left(\beta_{3}\right)$} & $0.3399^{* * *}$ & $0.5860^{* * *}$ & $0.3047^{* * *}$ & $0.3641^{* * *}$ & $0.5035^{* * *}$ & $0.3488^{* * *}$ \\
\hline & $(0.0430)$ & $(0.0704)$ & $(0.0574)$ & $(0.0504)$ & $(0.0758)$ & $(0.0691)$ \\
\hline \multirow[t]{2}{*}{ Schooling $\left(\beta_{4}\right)$} & $0.0261^{* * *}$ & $0.0273^{* * *}$ & -0.0068 & $0.0226^{* * *}$ & $0.0258^{* * *}$ & -0.0080 \\
\hline & $(0.0077)$ & $(0.0094)$ & $(0.0136)$ & $(0.0077)$ & $(0.0093)$ & $(0.0139)$ \\
\hline \multirow[t]{2}{*}{$G D P_{t-1}\left(\beta_{5}\right)$} & $-0.0741^{* * *}$ & $-0.0819^{* * *}$ & $-0.1172^{* * *}$ & $-0.0821^{* * *}$ & $-0.1147^{* * *}$ & $-0.1100^{* * *}$ \\
\hline & $(0.0125)$ & $(0.0155)$ & $(0.0222)$ & $(0.0137)$ & $(0.0193)$ & $(0.0222)$ \\
\hline \multirow{2}{*}{$D_{\text {Crisis }}\left(\beta_{6}\right)$} & $-0.0799^{* * *}$ & $-0.0823^{* * *}$ & $-0.0723^{* * *}$ & $-0.0793^{* * *}$ & $-0.0802^{* * *}$ & $-0.0739^{* * *}$ \\
\hline & $(0.0039)$ & $(0.0052)$ & $(0.0058)$ & $(0.0040)$ & $(0.0052)$ & $(0.0058)$ \\
\hline \multirow{2}{*}{$D_{\text {LElection }}\left(\beta_{7}\right)$} & $0.0424^{* * *}$ & $0.0425^{* * *}$ & $0.0376^{* * *}$ & $0.0425^{* * *}$ & $0.0474^{* * * *}$ & $0.0346^{* * *}$ \\
\hline & $(0.0062)$ & $(0.0082)$ & $(0.0091)$ & $(0.0063)$ & $(0.0084)$ & $(0.0092)$ \\
\hline \multirow[t]{2}{*}{ Intercept $\left(\beta_{0}\right)$} & $0.7954^{* * *}$ & $0.6499^{* * *}$ & $1.5357^{* * *}$ & $0.9452^{* * *}$ & $1.1222^{* * *}$ & $1.4442^{* * *}$ \\
\hline & $(0.1630)$ & $(0.1799)$ & $(0.2957)$ & $(0.1873)$ & $(0.2455)$ & $(0.3022)$ \\
\hline Adjusted $R^{2}$ & 0.3320 & 0.3704 & 0.3250 & 0.3367 & 0.3775 & 0.3266 \\
\hline$N$ & 1225 & 747 & 478 & 1225 & 747 & 478 \\
\hline
\end{tabular}

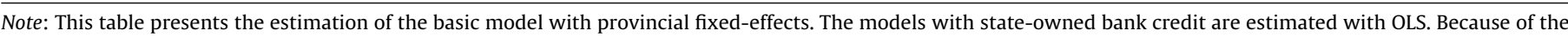
endogenity problem, an IV method is used in the estimations of models with private bank credit.

* Statistical significance at the $10 \%$ level.

** Statistical significance at the $5 \%$ level.

*** Statistical significance at the $1 \%$ level.

still surprising that credit from private banks in the developed provinces is not found to be significantly associated with the welfare of these provinces.

Table 3 shows that state-owned banks have a significantly higher share in less-developed provinces. The insignificant coefficient on per capita credit from these banks in the less-developed provinces suggests that this credit might be used to finance social projects or to fix market failures in these provinces. An alternative explanation might be the political use of state-owned bank loans. However, per capita credit issued by private banks and foreign banks has a significant and positive association with individuals' per capita income in less-developed regions. This finding indicates that private banks might have better technologies to identify productive projects in those regions and may better monitor them to yield more return to local investors, supporting the result from De la Torre et al. (2010). They show that all types of banks (large, small, domestic, and foreign) expand their operations in the SME segment and compete with state-owned banks aggressively. They argue that private banks, including foreign banks, have comparative advantages in offering a wide range of products and services through the use of new technologies for monitoring and managing risks.

Similar to other studies in the literature, public expenditures per capita and urbanization have a positive association with the local growth rate. The positive coefficient on public expenditures is significant in all and less-developed provinces. Considering the types of public expenditures made in these provinces, such as infrastructure, education, and health, it is not surprising to see this effect. Schooling has a positive and significant effect on local growth for all and less-developed provinces. Because this variable is measured by the number of high school students per high school teachers, an increase in it might result in a decline in the quality of education. However, considering an average 17.6 high school students per teacher, it can be argued that an increase in this number also indicates an increase in human capital, which would have a positive effect on the growth of per capita provincial income. As expected, the growth rate in per capita GDP declines significantly in crisis years. Controlling for bank credit and public expenditures, years with local elections have a higher growth rate than other years.

\subsection{Bank credit and local growth in crisis years}

Table 5 reports the results of the fixed-effects model with the crisis interaction variable. Per capita state-owned bank credit is found to be positively and significantly related to the growth rate of real per capita GDP in the Turkish provinces, controlling for other factors that might affect provincial growth, such as public expenditures, urbanization, schooling, and a province's initial real GDP. It holds for all provinces as well as the developed and lessdeveloped provinces; however, the coefficient is only significant when all provinces are included in the analysis.

The coefficient on the interaction variable between per capita state-owned bank credit and the crisis dummy variable is significant in the developed provinces. When these two coefficients are added, per capita state-owned bank credit is found to have a positive and significant relationship with local growth in crisis years. This result suggests that per capita loans issued by state-owned banks in crisis years help increase the growth level in the developed Turkish provinces as well as in all provinces. ${ }^{22} \mathrm{~A} 1 \%$ increase in per capita state-owned bank credit in developed provinces in crisis years is expected to increase the growth rate of per capita real GDP in these provinces by $4.2 \%$. On the other hand, a similar increase in per capita state-owned bank credit issued in non-crisis years is found to increase the per capita real GDP growth rate by only $0.9 \%$. However, per capita state-owned bank credit in crisis years is not found to have a significant effect on local growth in less-developed provinces.

The results are slightly different for private bank credit. Although per capita credit from these banks has a positive association with local growth, the only significant and positive coefficient is found in the less-developed provinces, where private banks have

\footnotetext{
22 By slightly changing the model and using the provincial per capita credit growth rate of state-owned banks rather than the level of per capita bank credit as an independent variable, we try to estimate whether Turkish state-owned banks played a smoothing role in crisis periods. We find that the growth rate of state-owned bank credit per capita is positively and significantly associated with the growth rate of GDP per capita.
} 
Table 5

Bank credit and local growth in crisis years.

\begin{tabular}{|c|c|c|c|c|c|c|}
\hline & \multicolumn{3}{|c|}{ State-owned banks } & \multicolumn{3}{|l|}{ Private banks } \\
\hline & All provinces & Less-developed & Developed & All provinces & Less-developed & Developed \\
\hline Bank Credit $\left(\beta_{1}\right)$ & $\begin{array}{l}0.0086^{* *} \\
(0.0041)\end{array}$ & $\begin{array}{l}0.0074 \\
(0.0058)\end{array}$ & $\begin{array}{l}0.0088 \\
(0.0055)\end{array}$ & $\begin{array}{l}0.0066 \\
(0.0044)\end{array}$ & $\begin{array}{l}0.0179^{* *} \\
(0.0077)\end{array}$ & $\begin{array}{l}0.0019 \\
(0.0052)\end{array}$ \\
\hline$D_{\text {Crisis }} \times$ Bank Credit $\left(\beta_{8}\right)$ & $\begin{array}{l}0.0010 \\
(0.0055)\end{array}$ & $\begin{array}{l}-0.0063 \\
(0.0067)\end{array}$ & $\begin{array}{l}0.0334^{* * *} \\
(0.0102)\end{array}$ & $\begin{array}{l}-0.0819^{* * *} \\
(0.0137)\end{array}$ & $\begin{array}{l}0.0255^{* * * *} \\
(0.0088)\end{array}$ & $\begin{array}{l}-0.1085^{* * *} \\
(0.0223)\end{array}$ \\
\hline Public Expenditures $\left(\beta_{2}\right)$ & $\begin{array}{l}0.0645^{* * *} \\
(0.0188)\end{array}$ & $\begin{array}{l}0.0906^{* * *} \\
(0.0272)\end{array}$ & $\begin{array}{l}0.0170 \\
(0.0248)\end{array}$ & $\begin{array}{l}0.3657^{* * *} \\
(0.0503)\end{array}$ & $\begin{array}{l}0.1052^{* * *} \\
(0.0266)\end{array}$ & $\begin{array}{l}0.3485^{* * *} \\
(0.0691)\end{array}$ \\
\hline Urbanization $\left(\beta_{3}\right)$ & $\begin{array}{l}0.3404^{* * *} \\
(0.0431)\end{array}$ & $\begin{array}{l}0.5771^{* * *} \\
(0.0710)\end{array}$ & $\begin{array}{l}0.3028^{* * *} \\
(0.0568)\end{array}$ & $\begin{array}{l}0.0229^{* * * *} \\
(0.0077)\end{array}$ & $\begin{array}{l}0.5344^{* * *} \\
(0.0761)\end{array}$ & $\begin{array}{l}-0.0077 \\
(0.0139)\end{array}$ \\
\hline Schooling $\left(\beta_{4}\right)$ & $\begin{array}{l}0.0261^{* * *} \\
(0.0077)\end{array}$ & $\begin{array}{l}0.0272^{* * *} \\
(0.0094)\end{array}$ & $\begin{array}{l}-0.0086 \\
(0.0134)\end{array}$ & $\begin{array}{l}-0.0835^{* * *} \\
(0.0046)\end{array}$ & $\begin{array}{l}0.0256^{* * *} \\
(0.0092)\end{array}$ & $\begin{array}{l}-0.0779^{* * *} \\
(0.0076)\end{array}$ \\
\hline$G D P_{t-1}\left(\beta_{5}\right)$ & $\begin{array}{l}-0.0740^{* * *} \\
(0.0125)\end{array}$ & $\begin{array}{l}-0.0822^{* * *} \\
(0.0155)\end{array}$ & $\begin{array}{l}-0.1204^{* * *} \\
(0.0220)\end{array}$ & $\begin{array}{l}0.0773^{* * *} \\
(0.0192)\end{array}$ & $\begin{array}{l}-0.1228^{* * *} \\
(0.0194)\end{array}$ & $\begin{array}{l}0.0150 \\
(0.0264)\end{array}$ \\
\hline$D_{\text {Crisis }}\left(\beta_{6}\right)$ & $\begin{array}{l}-0.0804^{* * *} \\
(0.0050)\end{array}$ & $\begin{array}{l}-0.0793^{* * *} \\
(0.0061)\end{array}$ & $\begin{array}{l}-0.0942^{* * *} \\
(0.0088)\end{array}$ & $\begin{array}{l}0.0423^{* * *} \\
(0.0063)\end{array}$ & $\begin{array}{l}-0.0903^{* * *} \\
(0.0062)\end{array}$ & $\begin{array}{l}0.0345^{* * *} \\
(0.0092)\end{array}$ \\
\hline$D_{\text {LElection }}\left(\beta_{7}\right)$ & $\begin{array}{l}0.0424^{* * *} \\
(0.0063)\end{array}$ & $\begin{array}{l}0.0427^{* * *} \\
(0.0082)\end{array}$ & $\begin{array}{l}0.0375^{* * * *} \\
(0.0090)\end{array}$ & $\begin{array}{l}0.0048^{*} \\
(0.0027)\end{array}$ & $\begin{array}{l}0.0463^{* * *} \\
(0.0083)\end{array}$ & $\begin{array}{l}0.0024 \\
(0.0029)\end{array}$ \\
\hline Intercept $\left(\beta_{0}\right)$ & $\begin{array}{l}0.7950^{* * *} \\
(0.1631)\end{array}$ & $\begin{array}{l}0.6586^{* * *} \\
(0.1801)\end{array}$ & $\begin{array}{l}1.5897^{* * *} \\
(0.2929)\end{array}$ & $\begin{array}{l}0.9421^{* * *} \\
(0.1871)\end{array}$ & $\begin{array}{l}1.2110^{* * * *} \\
(0.2461)\end{array}$ & $\begin{array}{l}1.4246^{* * *} \\
(0.3032)\end{array}$ \\
\hline Interaction $\left(\beta_{1}+\beta_{8}\right)$ & $0.0097^{*}$ & 0.0011 & $0.0422^{* * *}$ & $-0.0753^{* *}$ & $0.0434^{* * *}$ & -0.1066 \\
\hline$F$-statistics & 3.12 & 0.03 & 16.24 & 5.65 & 17.20 & 0.63 \\
\hline$p$-Value & 0.0777 & 0.8697 & 0.0001 & 0.0176 & 0.0000 & 0.4294 \\
\hline Adjusted $R^{2}$ & 0.3315 & 0.3703 & 0.3396 & 0.3379 & 0.3841 & 0.3229 \\
\hline$N$ & 1225 & 747 & 478 & 1225 & 747 & 478 \\
\hline
\end{tabular}

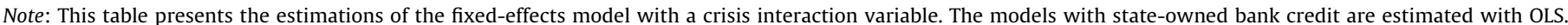
Because of the endogenity problem, an IV method is used in the estimations of models with private bank credit. The $F$-statistic tests whether $\left(\beta_{1}+\beta_{8}\right)=0$.

* Statistical significance at the $10 \%$ level.

${ }^{* *}$ Statistical significance at the $5 \%$ level.

*** Statistical significance at the $1 \%$ level.

a lower share of the credit market. In crisis years, the coefficient on per capita private bank credit changes significantly in all three groups of provinces. The coefficient increases in less-developed provinces, whereas it declines in all provinces and in developed provinces. This negative or insignificant coefficient can be observed if private banks issue credit in crisis periods to be used as working capital rather than for investment purposes.

\subsection{Bank credit and local growth in election years}

Table 6 presents the results of the fixed-effects model with a local election and bank credit interaction variable. The results are consistent with the previous findings that per capita stateowned bank credit is positively and significantly associated with local growth in all provinces as well as in developed provinces. Even though state-owned banks have a significantly higher share in credit markets in local election years (Table 3 ), the regression findings indicate that, controlling for other factors that might affect growth, the coefficient of per capita credit provided by stateowned banks does not change significantly in these years. When the combined effects are considered, the results suggest that per capita credit from state-owned banks in local election years does not benefit individuals' well-being in any Turkish provinces. This finding supports the other findings in the literature that stateowned banks might provide credit for political reasons in local elections.

To further investigate the insignificant coefficient of stateowned bank credit per capita during election periods, we run our model for a sample of provinces where the incumbent is a member of the governing party in the year of a local election. In this way, we aim to examine whether funding by state-owned banks is mainly used to provide benefits to provinces that are populated with supporters of the governing party. We find that the coefficient on per capita state-owned bank credit is positive and significant, but in local election years this coefficient becomes significant and negative, which suggests that state-owned banks provide politically connected credit during local election years. ${ }^{23}$

When we examine per capita private bank credit, its association with local growth is found to be positive and significant in all provinces and in less-developed provinces. This coefficient declines significantly in local election years. However, the combined effect of credit in these years is found to be insignificant in all provinces regardless of their development level.

Table 7 presents the results of the fixed effects model with a general election interaction variable. Consistent with other models, state-owned bank credit per capita is found to increase local growth rate significantly in all and developed provinces whereas private bank credit per capita is found to increase local growth significantly in less-developed provinces. Although the coefficient on the interaction variable is found to be negative and significant in some provinces, the only significant and positive combined coefficient is observed for private bank credit in less-developed provinces. In general, credit from both types of banks is not significantly associated with the growth rate of per capita real GDP in the Turkish provinces in general election years. This insignificant finding might be explained by the firms' behavior. They might postpone their investments during election periods. Julio and Yook (2012) examine 248 elections in 48 countries and find that firms reduce investment expenditures during national election years by an average of $4.8 \%$, controlling for growth opportunities and economic conditions. They argue that political uncertainty creates uncertainty about future investment payoffs; and, in response, rational managers postpone investments until the uncertainty is resolved. Our findings suggest that Turkish firms might behave in a similar

${ }^{23}$ We do not report the results of this estimation to save space. They are available from the authors upon request. 
Table 6

Bank credit and local growth in local election years.

\begin{tabular}{|c|c|c|c|c|c|c|}
\hline & \multicolumn{3}{|c|}{ State-owned banks } & \multicolumn{3}{|l|}{ Private banks } \\
\hline & All provinces & Less-developed & Developed & All provinces & Less-developed & Developed \\
\hline Bank Credit $\left(\beta_{1}\right)$ & $\begin{array}{l}0.0090^{* *} \\
(0.0038)\end{array}$ & $\begin{array}{l}0.0047 \\
(0.0052)\end{array}$ & $\begin{array}{l}0.0126^{* *} \\
(0.0054)\end{array}$ & $\begin{array}{l}0.0081^{*} \\
(0.0044)\end{array}$ & $\begin{array}{l}0.0224^{* * *} \\
(0.0075)\end{array}$ & $\begin{array}{l}0.0027 \\
(0.0051)\end{array}$ \\
\hline$D_{\text {LElection }} \times$ BankCredit $\left(\beta_{8}\right)$ & $\begin{array}{l}-0.0016 \\
(0.0104)\end{array}$ & $\begin{array}{l}0.0017 \\
(0.0112)\end{array}$ & $\begin{array}{l}-0.0043 \\
(0.0411)\end{array}$ & $\begin{array}{l}-0.0824^{* * *} \\
(0.0138)\end{array}$ & $\begin{array}{l}0.0014 \\
(0.0363)\end{array}$ & $\begin{array}{l}-0.1100^{* * *} \\
(0.0223)\end{array}$ \\
\hline Public Expenditures $\left(\beta_{2}\right)$ & $\begin{array}{l}0.0643^{* * *} \\
(0.0188)\end{array}$ & $\begin{array}{l}0.0922^{* * *} \\
(0.0272)\end{array}$ & $\begin{array}{l}0.0101 \\
(0.0250)\end{array}$ & $\begin{array}{l}0.3629^{* * *} \\
(0.0504)\end{array}$ & $\begin{array}{l}0.1087^{* * *} \\
(0.0268)\end{array}$ & $\begin{array}{l}0.3485^{* * *} \\
(0.0693)\end{array}$ \\
\hline Urbanization $\left(\beta_{3}\right)$ & $\begin{array}{l}0.3396^{* * *} \\
(0.0431)\end{array}$ & $\begin{array}{l}0.5865^{* * *} \\
(0.0705)\end{array}$ & $\begin{array}{l}0.3044^{* * *} \\
(0.0575)\end{array}$ & $\begin{array}{l}0.0227^{* * *} \\
(0.0077)\end{array}$ & $\begin{array}{l}0.5034^{* * *} \\
(0.0758)\end{array}$ & $\begin{array}{l}-0.0079 \\
(0.0139)\end{array}$ \\
\hline Schooling $\left(\beta_{4}\right)$ & $\begin{array}{l}0.0261^{* * *} \\
(0.0077)\end{array}$ & $\begin{array}{l}0.0273^{* * *} \\
(0.0094)\end{array}$ & $\begin{array}{l}-0.0068 \\
(0.0136)\end{array}$ & $\begin{array}{l}-0.0793^{* * *} \\
(0.0040)\end{array}$ & $\begin{array}{l}0.0258^{* * *} \\
(0.0093)\end{array}$ & $\begin{array}{l}-0.0738^{* * *} \\
(0.0058)\end{array}$ \\
\hline$G D P_{t-1}\left(\beta_{5}\right)$ & $\begin{array}{l}-0.0741^{* * *} \\
(0.0125)\end{array}$ & $\begin{array}{l}-0.0818^{* * *} \\
(0.0155)\end{array}$ & $\begin{array}{l}-0.1172^{* * *} \\
(0.0222)\end{array}$ & $\begin{array}{l}0.0784^{* * *} \\
(0.0192)\end{array}$ & $\begin{array}{l}-0.1147^{* * *} \\
(0.0193)\end{array}$ & $\begin{array}{l}0.0153 \\
(0.0266)\end{array}$ \\
\hline$D_{\text {Crisis }}\left(\beta_{6}\right)$ & $\begin{array}{l}-0.0799^{* * *} \\
(0.0039)\end{array}$ & $\begin{array}{l}-0.0823^{* * *} \\
(0.0052)\end{array}$ & $\begin{array}{l}-0.0723^{* * *} \\
(0.0058)\end{array}$ & $\begin{array}{l}0.0453^{* * *} \\
(0.0072)\end{array}$ & $\begin{array}{l}-0.0802^{* * *} \\
(0.0052)\end{array}$ & $\begin{array}{l}0.0354^{* * *} \\
(0.0117)\end{array}$ \\
\hline$D_{\text {LElection }}\left(\beta_{7}\right)$ & $\begin{array}{l}0.0431^{* * *} \\
(0.0077)\end{array}$ & $\begin{array}{l}0.0419^{* * *} \\
(0.0093)\end{array}$ & $\begin{array}{l}0.0397^{*} \\
(0.0220)\end{array}$ & $\begin{array}{l}-0.0040 \\
(0.0049)\end{array}$ & $\begin{array}{l}0.0470^{* * *} \\
(0.0123)\end{array}$ & $\begin{array}{l}-0.0006 \\
(0.0050)\end{array}$ \\
\hline Intercept $\left(\beta_{0}\right)$ & $\begin{array}{l}0.7965^{* * *} \\
(0.1632)\end{array}$ & $\begin{array}{l}0.6484^{* * *} \\
(0.1803)\end{array}$ & $\begin{array}{l}1.5355^{* * *} \\
(0.2960)\end{array}$ & $\begin{array}{l}0.9493^{* * *} \\
(0.1873)\end{array}$ & $\begin{array}{l}1.1222^{* * *} \\
(0.2457)\end{array}$ & $\begin{array}{l}1.4449^{* * *} \\
(0.3026)\end{array}$ \\
\hline Interaction $\left(\beta_{1}+\beta_{8}\right)$ & 0.0074 & 0.0064 & 0.0083 & -0.0743 & 0.0238 & -0.1073 \\
\hline$F$-statistics & 0.49 & 0.31 & 0.04 & 0.41 & 0.41 & 0.10 \\
\hline$p$-Value & 0.4859 & 0.5771 & 0.8413 & 0.5226 & 0.5221 & 0.7508 \\
\hline Adjusted $R^{2}$ & 0.3315 & 0.3695 & 0.3235 & 0.3365 & 0.3766 & 0.3218 \\
\hline$N$ & 1225 & 747 & 478 & 1225 & 747 & 478 \\
\hline
\end{tabular}

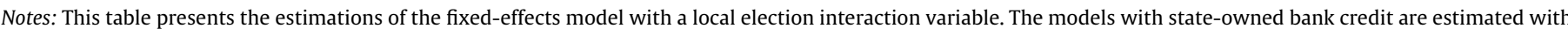
OLS. Because of the endogenity problem, an IV method is used in the estimations of models with private bank credit. $F$-statistic tests whether $\left(\beta_{1}+\beta_{8}\right)=0$.

* Statistical significance at the $10 \%$ level.

** Statistical significance at the $5 \%$ level.

*** Statistical significance at the $1 \%$ level.

way during general election periods. As seen in Table 2, both types of banks lend less in general election years.

It can be argued that there may be an endogeneity problem with the general election variable if the election was conducted outside the usual schedule because of economic turmoil. During our sample period, all general elections in Turkey were conducted in their scheduled year (i.e., every four years), except for the planned 2002 election, which was conducted one year earlier to resolve political

Table 7

Bank credit and local growth in general election years.

\begin{tabular}{|c|c|c|c|c|c|c|}
\hline \multirow[b]{2}{*}{ All } & \multicolumn{3}{|c|}{ State-owned banks } & \multicolumn{3}{|l|}{ Private banks } \\
\hline & Less-developed & Developed & All & Less-developed & Developed & \\
\hline Bank Credit $\left(\beta_{1}\right)$ & $\begin{array}{l}0.0082^{* *} \\
(0.0040)\end{array}$ & $\begin{array}{l}0.0044 \\
(0.0054)\end{array}$ & $\begin{array}{l}0.0142^{* *} \\
(0.0058)\end{array}$ & $\begin{array}{l}0.0035 \\
(0.0044)\end{array}$ & $\begin{array}{l}0.0173^{* *} \\
(0.0078)\end{array}$ & $\begin{array}{l}-0.0002 \\
(0.0051)\end{array}$ \\
\hline$D_{\text {GElection }} \times$ Bank Credit $\left(\beta_{8}\right)$ & $\begin{array}{l}-0.0054 \\
(0.0060)\end{array}$ & $\begin{array}{l}-0.0007 \\
(0.0078)\end{array}$ & $\begin{array}{l}-0.0214^{* *} \\
(0.0093)\end{array}$ & $\begin{array}{l}-0.0773^{* * *} \\
(0.0141)\end{array}$ & $\begin{array}{l}0.0040 \\
(0.0090)\end{array}$ & $\begin{array}{l}-0.1022^{* * *} \\
(0.0228)\end{array}$ \\
\hline Public Expenditures $\left(\beta_{2}\right)$ & $\begin{array}{l}0.0475^{* *} \\
(0.0194)\end{array}$ & $\begin{array}{l}0.0707^{* *} \\
(0.0279)\end{array}$ & $\begin{array}{l}-0.0074 \\
(0.0257)\end{array}$ & $\begin{array}{l}0.4128^{* * *} \\
(0.0508)\end{array}$ & $\begin{array}{l}0.0822^{* * *} \\
(0.0274)\end{array}$ & $\begin{array}{l}0.3741^{* * *} \\
(0.0699)\end{array}$ \\
\hline Urbanization $\left(\beta_{3}\right)$ & $\begin{array}{l}0.3613^{* * *} \\
(0.0438)\end{array}$ & $\begin{array}{l}0.6304^{* * *} \\
(0.0709)\end{array}$ & $\begin{array}{l}0.2944^{* * *} \\
(0.0590)\end{array}$ & $\begin{array}{l}0.0269^{* * *} \\
(0.0079)\end{array}$ & $\begin{array}{l}0.5704^{* * *} \\
(0.0759)\end{array}$ & $\begin{array}{l}-0.0064 \\
(0.0142)\end{array}$ \\
\hline Schooling $\left(\beta_{4}\right)$ & $\begin{array}{l}0.0291^{* * *} \\
(0.0079)\end{array}$ & $\begin{array}{l}0.0316^{* * *} \\
(0.0096)\end{array}$ & $\begin{array}{l}-0.0105 \\
(0.0141)\end{array}$ & $\begin{array}{l}-0.0862^{* * *} \\
(0.0041)\end{array}$ & $\begin{array}{l}0.0318^{* * *} \\
(0.0097)\end{array}$ & $\begin{array}{l}-0.0785^{* * *} \\
(0.0060)\end{array}$ \\
\hline$G D P_{t-1}\left(\beta_{5}\right)$ & $\begin{array}{l}-0.0733^{* * *} \\
(0.0128)\end{array}$ & $\begin{array}{l}-0.0851^{* * *} \\
(0.0157)\end{array}$ & $\begin{array}{l}-0.1049^{* * *} \\
(0.0228)\end{array}$ & $\begin{array}{l}0.0565^{* * *} \\
(0.0195)\end{array}$ & $\begin{array}{l}-0.1128^{* * *} \\
(0.0199)\end{array}$ & $\begin{array}{l}-0.0005 \\
(0.0268)\end{array}$ \\
\hline$D_{\text {Crisis }}\left(\beta_{6}\right)$ & $\begin{array}{l}-0.0863^{* * *} \\
(0.0041)\end{array}$ & $\begin{array}{l}-0.0897^{* * *} \\
(0.0054)\end{array}$ & $\begin{array}{l}-0.0773^{* * *} \\
(0.0060)\end{array}$ & $\begin{array}{l}-0.0090^{*} \\
(0.0050)\end{array}$ & $\begin{array}{l}-0.0889^{* * *} \\
(0.0054)\end{array}$ & $\begin{array}{l}0.0039 \\
(0.0077)\end{array}$ \\
\hline$D_{\text {GElection }}\left(\beta_{7}\right)$ & $\begin{array}{l}-0.0070 \\
(0.0051)\end{array}$ & $\begin{array}{l}-0.0138^{* *} \\
(0.0064)\end{array}$ & $\begin{array}{l}0.0098 \\
(0.0081)\end{array}$ & $\begin{array}{l}-0.0009 \\
(0.0030)\end{array}$ & $\begin{array}{l}-0.0184^{* * *} \\
(0.0070)\end{array}$ & $\begin{array}{l}-0.0045 \\
(0.0032)\end{array}$ \\
\hline Intercept $\left(\beta_{0}\right)$ & $\begin{array}{l}0.7709^{* * *} \\
(0.1668)\end{array}$ & $\begin{array}{l}0.6593^{* * *} \\
(0.1830)\end{array}$ & $\begin{array}{l}1.3853^{* * *} \\
(0.3030)\end{array}$ & $\begin{array}{l}0.8553^{* * *} \\
(0.1915)\end{array}$ & $\begin{array}{l}1.0481^{* * *} \\
(0.2514)\end{array}$ & $\begin{array}{l}1.3271^{* * *} \\
(0.3091)\end{array}$ \\
\hline Interaction $\left(\beta_{1}+\beta_{8}\right)$ & 0.0028 & 0.0037 & -0.0071 & -0.0738 & $0.0213^{* *}$ & -0.1024 \\
\hline F-statistics & 0.20 & 0.20 & 0.62 & 0.26 & 3.89 & 0.65 \\
\hline$p$-Value & 0.6568 & 0.6580 & 0.4329 & 0.6081 & 0.0490 & 0.4221 \\
\hline Adjusted $R^{2}$ & 0.3081 & 0.3513 & 0.3060 & 0.3133 & 0.3559 & 0.3036 \\
\hline$N$ & 1225 & 747 & 478 & 1225 & 747 & 478 \\
\hline
\end{tabular}


OLS. Because of the endogenity problem, an IV method is used in the estimations of models with private bank credit. The $F$-statistic tests whether $\left(\beta_{1}+\beta_{8}\right)=0$.

* Statistical significance at the $10 \%$ level.

** Statistical significance at the 5\% level.

*** Statistical significance at the $1 \%$ level. 
Table 8

Robustness checks.

\begin{tabular}{|c|c|c|c|c|c|c|}
\hline & \multicolumn{3}{|c|}{ State-owned banks } & \multicolumn{3}{|c|}{ Private banks } \\
\hline & All & Less-developed & Developed & All & Less-developed & Developed \\
\hline \multicolumn{7}{|c|}{ Panel A: Bank credit is defined as a percentage of provincial GDP } \\
\hline A.1 Bank Credit/GDP & $\begin{array}{l}5.038 \\
(28.428)\end{array}$ & $\begin{array}{l}-28.035 \\
(31.768)\end{array}$ & $\begin{array}{l}105.875 \\
(69.765)\end{array}$ & $\begin{array}{l}47.808 \\
(37.143)\end{array}$ & $\begin{array}{l}189.579^{* *} \\
(87.176)\end{array}$ & $\begin{array}{l}48.851 \\
(38.981)\end{array}$ \\
\hline A.2 Bank Credit/GDP & $\begin{array}{l}44.667 \\
(37.757)\end{array}$ & $\begin{array}{l}10.166 \\
(44.686)\end{array}$ & $\begin{array}{l}58.282 \\
(72.058)\end{array}$ & $\begin{array}{l}25.546 \\
(39.615)\end{array}$ & $\begin{array}{l}151.896^{*} \\
(88.508)\end{array}$ & $\begin{array}{l}34.552 \\
(42.078)\end{array}$ \\
\hline$D_{\text {Crisis }} \times$ BankCredit/GDP & $\begin{array}{l}-67.100 \\
(42.111)\end{array}$ & $\begin{array}{l}-57.045 \\
(46.946)\end{array}$ & $\begin{array}{l}365.363^{* *} \\
(149.531)\end{array}$ & $\begin{array}{l}58.835 \\
(36.582)\end{array}$ & $\begin{array}{l}297.472^{* *} \\
(131.808)\end{array}$ & $\begin{array}{l}34.411 \\
(38.081)\end{array}$ \\
\hline Interaction & -22.433 & -46.879 & $423.645^{* * *}$ & $84.381^{*}$ & $449.368^{* * *}$ & 68.964 \\
\hline A.3 Bank Credit/GDP & $\begin{array}{l}4.617 \\
(28.452)\end{array}$ & $\begin{array}{l}-28.307 \\
(31.799)\end{array}$ & $\begin{array}{l}104.175 \\
(70.085)\end{array}$ & $\begin{array}{l}46.750 \\
(37.195)\end{array}$ & $\begin{array}{l}196.456 \\
(89.279)\end{array}$ & $\begin{array}{l}48.650 \\
(39.171)\end{array}$ \\
\hline$D_{\text {LElection }} \times$ BankCredit $/ G D P$ & $\begin{array}{l}53.829 \\
(112.838)\end{array}$ & $\begin{array}{l}39.916 \\
(119.631)\end{array}$ & $\begin{array}{l}124.315 \\
(430.488)\end{array}$ & $\begin{array}{l}-55.697 \\
(91.859)\end{array}$ & $\begin{array}{l}-93.489 \\
(258.508)\end{array}$ & $\begin{array}{l}-5.894 \\
(99.175)\end{array}$ \\
\hline Interaction & 58.446 & 11.608 & 228.489 & -8.947 & 102.967 & 42.756 \\
\hline A.4 Bank Credit/GDP & $\begin{array}{l}1.290 \\
(30.706)\end{array}$ & $\begin{array}{l}-34.424 \\
(34.099)\end{array}$ & $\begin{array}{l}136.100^{*} \\
(76.991)\end{array}$ & $\begin{array}{l}30.171 \\
(38.115)\end{array}$ & $\begin{array}{l}161.728^{*} \\
(90.916)\end{array}$ & $\begin{array}{l}44.301 \\
(39.769)\end{array}$ \\
\hline$D_{\text {GElection }} \times$ BankCredit/GDP & $\begin{array}{l}-22.281 \\
(49.844)\end{array}$ & $\begin{array}{l}4.326 \\
(54.661)\end{array}$ & $\begin{array}{l}-240.366^{*} \\
(128.529)\end{array}$ & $\begin{array}{l}-57.511 \\
(43.686)\end{array}$ & $\begin{array}{l}-1.516 \\
(131.343)\end{array}$ & $\begin{array}{l}-106.670^{* *} \\
(45.428)\end{array}$ \\
\hline Interaction & -20.992 & -30.099 & -104.266 & -27.339 & 160.212 & -62.369 \\
\hline \multicolumn{7}{|c|}{ Panel B: The local election dummy variable takes a value of 1 for election years and the year before the election and 0 otherwise } \\
\hline B.1 Bank Credit & $\begin{array}{l}0.004 \\
(0.004)\end{array}$ & $\begin{array}{l}0.002 \\
(0.006)\end{array}$ & $\begin{array}{l}0.005 \\
(0.006)\end{array}$ & $\begin{array}{l}-0.002 \\
(0.003)\end{array}$ & $\begin{array}{l}0.016^{*} \\
(0.009)\end{array}$ & $\begin{array}{l}0.001 \\
(0.003)\end{array}$ \\
\hline$D_{\text {NewElection }} \times$ Bank Credit & $\begin{array}{l}0.015^{* *} \\
(0.006)\end{array}$ & $\begin{array}{l}0.011 \\
(0.008)\end{array}$ & $\begin{array}{l}0.019 \\
(0.012)\end{array}$ & $\begin{array}{l}0.003 \\
(0.004)\end{array}$ & $\begin{array}{l}0.055^{* *} \\
(0.023)\end{array}$ & $\begin{array}{l}0.004 \\
(0.004)\end{array}$ \\
\hline Interaction & $0.018^{* * *}$ & 0.013 & $0.024^{*}$ & 0.002 & $0.071^{* * *}$ & 0.005 \\
\hline \multicolumn{7}{|c|}{ Panel C: Provincial GDP growth rate is the dependent variable } \\
\hline C.1 Bank Credit & $\begin{array}{l}0.013^{* * *} \\
(0.003)\end{array}$ & $\begin{array}{l}0.013^{* * *} \\
(0.004)\end{array}$ & $\begin{array}{l}0.009^{*} \\
(0.005)\end{array}$ & $\begin{array}{l}0.002 \\
(0.002)\end{array}$ & $\begin{array}{l}0.020^{* * *} \\
(0.007)\end{array}$ & $\begin{array}{l}0.002 \\
(0.002)\end{array}$ \\
\hline C.2 Bank Credit & $\begin{array}{l}0.012^{* * *} \\
(0.004)\end{array}$ & $\begin{array}{l}0.013^{* * *} \\
(0.005)\end{array}$ & $\begin{array}{l}0.006 \\
(0.006)\end{array}$ & $\begin{array}{l}0.002 \\
(0.002)\end{array}$ & $\begin{array}{l}0.021^{* * *} \\
(0.007)\end{array}$ & $\begin{array}{l}0.002 \\
(0.002)\end{array}$ \\
\hline$D_{\text {Crisis }} \times$ Bank Credit & $\begin{array}{l}0.002 \\
(0.005)\end{array}$ & $\begin{array}{l}-0.002 \\
(0.006)\end{array}$ & $\begin{array}{l}0.029^{* * *} \\
(0.010)\end{array}$ & $\begin{array}{l}-0.002 \\
(0.002)\end{array}$ & $\begin{array}{l}-0.005 \\
(0.008)\end{array}$ & $\begin{array}{l}0.002 \\
(0.003)\end{array}$ \\
\hline Interaction & $0.015^{* * *}$ & $0.012^{* *}$ & $0.035^{* * *}$ & 0.000 & 0.015 & 0.003 \\
\hline C.3 Bank Credit & $\begin{array}{l}0.014^{* * *} \\
(0.003)\end{array}$ & $\begin{array}{l}0.013^{* * *} \\
(0.005)\end{array}$ & $\begin{array}{l}0.011^{* *} \\
(0.005)\end{array}$ & $\begin{array}{l}0.001 \\
(0.002)\end{array}$ & $\begin{array}{l}0.020^{* * *} \\
(0.007)\end{array}$ & $\begin{array}{l}0.002 \\
(0.002)\end{array}$ \\
\hline$D_{\text {LElection }} \times$ Bank Credit & $\begin{array}{l}-0.004 \\
(0.009)\end{array}$ & $\begin{array}{l}-0.003 \\
(0.010)\end{array}$ & $\begin{array}{l}-0.001 \\
(0.039)\end{array}$ & $\begin{array}{l}-0.003 \\
(0.004)\end{array}$ & $\begin{array}{l}0.007 \\
(0.029)\end{array}$ & $\begin{array}{l}0.000 \\
(0.005)\end{array}$ \\
\hline Interaction & 0.010 & 0.010 & 0.010 & -0.001 & 0.027 & 0.002 \\
\hline C.4 Bank Credit & $\begin{array}{l}0.014^{* * *} \\
(0.004)\end{array}$ & $\begin{array}{l}0.014^{* * *} \\
(0.005)\end{array}$ & $\begin{array}{l}0.013^{* *} \\
(0.006)\end{array}$ & $\begin{array}{l}0.000 \\
(0.002)\end{array}$ & $\begin{array}{l}0.018^{* *} \\
(0.007)\end{array}$ & $\begin{array}{l}0.001 \\
(0.002)\end{array}$ \\
\hline$D_{\text {GElection }} \times$ Bank Credit & $\begin{array}{l}-0.008 \\
(0.005)\end{array}$ & $\begin{array}{l}-0.006 \\
(0.007)\end{array}$ & $\begin{array}{l}-0.020^{* *} \\
(0.009)\end{array}$ & $\begin{array}{l}0.003 \\
(0.002)\end{array}$ & $\begin{array}{l}0.006 \\
(0.008)\end{array}$ & $\begin{array}{l}-0.003 \\
(0.003)\end{array}$ \\
\hline Interaction & 0.006 & 0.008 & -0.007 & 0.003 & $0.025^{* *}$ & -0.002 \\
\hline \multicolumn{7}{|c|}{ Panel D: Parameter estimates with year dummy variables } \\
\hline D.1 Bank Credit & $\begin{array}{l}0.011^{* * *} \\
(0.004)\end{array}$ & $\begin{array}{l}0.008 \\
(0.005)\end{array}$ & $\begin{array}{l}0.017^{* * *} \\
(0.006)\end{array}$ & $\begin{array}{l}0.027^{* * *} \\
(0.004)\end{array}$ & $\begin{array}{l}0.051^{* * *} \\
(0.006)\end{array}$ & $\begin{array}{l}0.016^{* * *} \\
(0.004)\end{array}$ \\
\hline D.2 Bank Credit & $\begin{array}{l}0.011^{* * *} \\
(0.004)\end{array}$ & $\begin{array}{l}0.011^{* *} \\
(0.006)\end{array}$ & $\begin{array}{l}0.013^{* *} \\
(0.006)\end{array}$ & $\begin{array}{l}0.026^{* * *} \\
(0.004)\end{array}$ & $\begin{array}{l}0.047^{* * * *} \\
(0.007)\end{array}$ & $\begin{array}{l}0.015^{* * *} \\
(0.005)\end{array}$ \\
\hline$D_{\text {Crisis }} \times$ Bank Credit & $\begin{array}{l}0.000 \\
(0.005\end{array}$ & $\begin{array}{r}-0.008 \\
(0.007)\end{array}$ & $\begin{array}{l}0.032^{* * *} \\
(0.010)\end{array}$ & $\begin{array}{l}0.003 \\
(0.003)\end{array}$ & $\begin{array}{l}0.010 \\
(0.009)\end{array}$ & $\begin{array}{l}0.002 \\
(0.003)\end{array}$ \\
\hline Interaction & $0.011^{* *}$ & 0.003 & $0.045^{* * *}$ & $0.029^{* * *}$ & $0.057^{* * *}$ & $0.017^{* * *}$ \\
\hline D.3 Bank Credit & $\begin{array}{l}0.011^{* * *} \\
(0.004)\end{array}$ & $\begin{array}{l}0.008 \\
(0.005)\end{array}$ & $\begin{array}{l}0.017^{* * *} \\
(0.006)\end{array}$ & $\begin{array}{l}0.028^{* * *} \\
(0.004)\end{array}$ & $\begin{array}{l}0.051^{* * *} \\
(0.006)\end{array}$ & $\begin{array}{l}0.016^{* * *} \\
(0.004)\end{array}$ \\
\hline$D_{\text {LElection }} \times$ Bank Credit & $\begin{array}{c}-0.003 \\
(0.010)\end{array}$ & $\begin{array}{l}0.000 \\
(0.011)\end{array}$ & $\begin{array}{l}-0.003 \\
(0.039)\end{array}$ & $\begin{array}{c}-0.005 \\
(0.005)\end{array}$ & $\begin{array}{l}0.007 \\
(0.033)\end{array}$ & $\begin{array}{l}-0.001 \\
(0.005)\end{array}$ \\
\hline Interaction & 0.008 & 0.008 & 0.014 & $0.023^{* * *}$ & $0.058^{*}$ & $0.015^{* *}$ \\
\hline D.4 Bank Credit & $\begin{array}{l}0.012^{* * *} \\
(0.004)\end{array}$ & $\begin{array}{l}0.009^{*} \\
(0.005)\end{array}$ & $\begin{array}{l}0.018^{* * *} \\
(0.006)\end{array}$ & $\begin{array}{l}0.027^{* * *} \\
(0.004)\end{array}$ & $\begin{array}{l}0.047^{* * *} \\
(0.006)\end{array}$ & $\begin{array}{l}0.016^{* * *} \\
(0.004)\end{array}$ \\
\hline$D_{\text {GElection }} \times$ Bank Credit & $\begin{array}{c}-0.005 \\
(0.006)\end{array}$ & $\begin{array}{c}-0.007 \\
(0.008)\end{array}$ & $\begin{array}{l}-0.007 \\
(0.010)\end{array}$ & $\begin{array}{l}0.001 \\
(0.003)\end{array}$ & $\begin{array}{l}0.069^{* * *} \\
(0.017)\end{array}$ & $\begin{array}{l}-0.002 \\
(0.003)\end{array}$ \\
\hline Interaction & 0.007 & 0.002 & 0.011 & $0.028^{* * *}$ & $0.116^{* * *}$ & $0.014^{*}$ \\
\hline
\end{tabular}

Note: The numbers in parentheses represent standard errors. Interaction represents the coefficient on the credit variable in crisis or election years.

* Statistical significance at the $10 \%$ level.

** Statistical significance at the $5 \%$ level.

*** Statistical significance at the $1 \%$ level. 
instability. When we estimate our model excluding the observations in 2002, the significance of our results does not change. The positive and significant association between local growth rate and state-owned bank credit is observed in all provinces and in developed provinces, and like other findings, their significance disappears in general election years but remains in crisis years.

The findings with respect to control variables are similar to the other studies in the literature. Interestingly, the growth rate of GDP per capita is significantly lower in general election years in lessdeveloped provinces, although they generally have a significantly higher growth rate in local election years.

\subsection{Robustness checks}

As a robustness check, we redefine bank credit as a percentage of GDP rather than per capita. Panel A of Table 8 reports only the coefficients of bank credit variables. No significant coefficient on state-owned bank credit is observed for all provinces. However, credit provided by state-owned banks during crisis years is found to increase local growth in developed provinces. Furthermore, although state-owned bank credit has a positive effect on growth in the Turkish provinces, the effect declines significantly in general election years. On the other hand, private bank credit has a positive and significant association with the growth rate of less-developed provinces. The positive and significant coefficient on private credit is observed in crisis periods as well.

It can be argued that if local elections occur in the first half of the year, the government might start election-related spending in the year prior to election. Therefore, we redefine the local election dummy variable by including the year before the local elections and estimate our models with this new variable, $D_{\text {NewElection. }}$. Panel B of Table 8 presents the estimated coefficients on credit-related variables and the total effect of credit during local election years. We find that credit provided by state-owned banks increases local growth rate in local election years in all provinces and developed provinces. However, none of the state-owned bank credit-related variables is found to significantly affect growth rate in the lessdeveloped provinces.

On the other hand, credit issued by private banks in pre-election and local election years is positively and significantly associated with per capita GDP growth rate of less-developed provinces. However, no significant coefficient of per capita credit issued by private banks is found in all and developed provinces. This result supports our previous findings and the existence of a political business cycle. Governments seem to engage in expansionary fiscal policies before elections to enhance their re-election prospects, and pursue contractionary policies after elections. In Turkey, all local elections are in the first quarter of the year, hence, fiscal contractions (Schuknecht, 1996) or increasing uncertainty (Julio and Yook, 2012) might lower investments and bank borrowing in election years.

To determine whether internal migration among regions affects our results, we estimate our model using the real GDP growth rate at the provincial level as another dependent variable. Although the quality and direction of migration vary by period in Turkey, the movement follows a pattern from less-developed regions to more developed regions. Because of the unavailability of yearly internal migration data before 2008 , we could not control for migration directly; instead, we include the growth rate in population in addition to the other control variables in the model. The coefficients on credit variables and interaction effects are reported in Panel $\mathrm{C}$ of Table 8. A positive and significant coefficient on per capita state-owned bank credit is obtained for all provinces, regardless of their development level. The total effect of state-owned bank credit in crisis years is found to be positive and significant in developed provinces, supporting our previous findings of per capita growth rate. On the other hand, credit provided by state-owned banks during general election years is negatively and significantly related to the growth rate of income in developed provinces. Interestingly, the coefficient on private bank credit is found to be positive and significant only in less-developed provinces.

We also estimate our models by including year dummy variables randomly to the model (Panel D in Table 8). Our results with respect to state-owned bank credit are found to be robust to the inclusion of year effects. For example, the coefficient on state-owned bank credit is positive and significant in all provinces and in developed provinces; as well as during crisis periods in these provinces. However, all the coefficients on private bank credit are found to be significant and positive in all models, including crisis, local election, and general election periods.

\section{Conclusion}

We examine per capita credit issued by state-owned and private banks in Turkey to understand their role in the growth of Turkish provinces with different development levels, especially in crisis and election years. Similar to most other developing countries, stateowned banks conduct a significant amount of the banking business in Turkey. Although these banks operate in similar fields of business as private banks, the remaining differences are considerable (see, for example, Hanson, 2004). For example, low refinancing costs and implicit government guarantees allow them to issue riskier loans than private banks can. State banks might provide financing on non-commercial terms to economically underdeveloped regions. They might fill the credit gap during distress periods. However, the current empirical literature shows that state-owned banks around the world are characterized by political interference, low accountability to stakeholders, inadequate prudential regulation and supervision, and a lack of proper incentives.

In this paper, we find that state-owned banks in Turkey have a significantly higher share in the credit markets of less-developed regions in local election years and crisis periods. The results of the fixed-effects models indicate that per capita provincial credit provided by commercial banks regardless of their ownership is found to have a positive and significant effect on local economic growth. Although per capita credit provided by state-owned banks in crisis years has a significant and positive association with local growth in all and developed provinces, per capita credit provided by private banks is positively associated with the growth rate of local per capita income in crisis years and in less-developed provinces. Overall, our results suggest that state-owned banks might issue loans for political reasons during election periods, but they still continue to play a significant role in offsetting the adverse effects of economic shocks, especially in the developed regions. Although a crisis is a rare event, these banks seem to still be important for local growth.

The insignificant association between provincial growth rate and per capita credit issued by private banks in developed provinces and that between provincial growth and per capita credit issued by state-owned banks in less-developed provinces can be explained by the inefficiency of these banks in the corresponding provinces. Hasan et al. (2009) state that banks might promote productivity growth through three ways: more credit, more efficient banking, and their interaction. Even though Turkish banks provide more credit in these provinces, they may not be efficient. As a further study, if bank efficiency measures at a provincial level are available in the future, the impact of bank efficiency and its interaction with credit can be examined to explain why we observe insignificant association in provinces where more credit has been provided by state-owned banks. 
There are two important caveats of the paper. First, the results of this study should be interpreted with caution, similar to other finance-growth studies that analyze the relationship between growth and financial services provided by government. As Rodrik (2005) states, government ownership of banks could be a policy choice to achieve some economic or political objectives. Second, the scarcity of data at the provincial level limits us in investigating whether other state-owned financial institutions, such as the Small and Medium Enterprises Development Organization, address market failures by providing direct financial support to sectors or regions inadequately served by state-owned banks. More precisely, it may be possible to see the effect of direct subsidies of stateowned institutions instead of involvement of state-owned banks in the purely commercial and most profitable parts of the market. For example, as emphasized in Yaron (2004), Hanson (2004) and De la Torre et al. (2007), direct subsidies may access to credit for small and medium-size enterprises and reduce the possibility of originating poor loans and the political manipulation of lending by state-owned banks. However, analyzing such a hypothesis and deriving more effective involvement of state-owned financial institutions go beyond the scope of this paper because of data limitation at the provincial level.

\section{Acknowledgments}

We would like to thank Iftekar Hasan (the Editor) and the anonymous referees for their useful comments and suggestions.

\section{References}

Alp, H., Elekdag, S., 2011. The role of monetary policy in Turkey during the global financial crisis. IMF Working Papers 11/150.

Alper, C.E., Onis, Z., 2004. The Turkish banking system and the IMF in the age of capital account liberalization. New Perspectives on Turkey 30, 25-55.

Andrianova, S., Demetriades, P., Shortland, A., 2012. Government ownership of banks, institutions and economic growth. Economica 79, 449-469.

Atkinson, A.B., Stiglitz, J.E., 1980. Lectures on Public Economics. Mc-Graw Hill, London.

Baum, C.F., Caglayan, M., Talavera, O., 2010. Parliamentary election cycles and the Turkish banking sector. Journal of Banking and Finance 34, 2709-2719.

Beck, T., Levine, R., Loayza, N., 2000. Finance and sources of growth. Journal of Financial Economics 58 (1-2), 261-300.

Beck, T., Demirguc-Kunt, A., 2006. Small and medium-size enterprises: access to finance as growth constraint. Journal of Banking and Finance 30, 2931-2943.

Beck, T., Demirguc-Kunt, A., Martinez Peria, M.S., 2011. Bank financing for SMEs: evidence across countries and bank ownership types. Journal of Financial Services Research 39, 35-54.

Bernanke, B.S., Lown, C.S., 1991. The credit crunch. Brookings Papers on Economic Activity 2, 205-247.

Bongini, P., Claessens, S., Ferri, G., 2001. The political economy of distress in East Asian financial institutions. Journal of Financial Services Research 19, $5-25$.

Brodjonegoro, B.P.S., 2002. The impact of the Asian economic crisis on regional development patterns in Indonesia. EADN Working Papers RPI-1.

BRSA, 2010. From crisis to financial stability (Turkey experience). Banking Regulation and Supervision Agency Working Paper.

Burgess, R., Pande, R., 2005. Do rural banks matter? Evidence from the Indian social banking experiment. American Economic Review 95, 780-795.

CBRT, 2010. Contribution of state-owned banks and private banks to credit growth during the global crisis. Central Bank of Republic of Turkey Economic Notes No. $10 / 09$.

Clarke, G.R.G., Cull, R., Martinez Peria, M.S., Sànchez, S.M., 2005. Bank lending to small businesses in Latin America: does bank origin matter? Journal of Money Credit and Banking 37, 87-113.

Cole, S., 2009. Fixing market failures or fixing elections?, Elections, banks and agricultural lending in India. American Economic Journal: Applied Economics 1, 219-250.
Cornett, M.M., Guo, L., Khaksari, S., Tehranian, H., 2010. Performance differences in privately-owned versus state-owned banks: an international comparison. Journal of Financial Intermediation 19, 74-94.

De la Torre, A., Gozzi, J.C., Schmukler, S.L., 2007. Innovative experiences in access to finance: market-friendly roles for the visible hand? Policy Research Working Paper 4326, World Bank, Washington, DC.

De la Torre, A., Martinez Peria, M.S., Schmukler, S.L., 2010. Bank involvement with SMEs: beyond relationship lending. Journal of Banking and Finance 34 2280-2293.

Detragiache, E., Gupta, P., 2006. Foreign banks in emerging market crises: evidence from Malaysia. Journal of Financial Stability 2, 217-242.

Dinç, I.S., 2005. Politicians and banks: political influences on public banks in emerging countries. Journal of Financial Economics 77, 453-479.

Guidotti, P.E., Rojas-Suarez, L., Zahler, R., 2004. Designing financial regulatory policies that work for Latin America: the role of markets and institutions: views from the Latin American shadow financial regulatory committee. Journal of Financial Stability $1,199-228$.

Hanson, J., 2004. The transformation of state-owned banks. In: Caprio, G., Fiechter, J., Litan, R., Pomerleano, M. (Eds.), The Future of State-Owned Financial Institutions. Brookings Institution Press, Washington, DC, pp. 13-49.

Hasan, I., Koetter, M., Wedow, M., 2009. Regional growth and finance in Europe: is there a quality effect of bank efficiency? Journal of Banking and Finance 33, 1446-1453.

International Finance Corporation, 2010. Access to Finance Annual Review Report 2010.

Imai, M., 2009. Political determinants of government loans in Japan. Journal of Law and Economics 52, 41-70

Incioglu, N., 2002. Local elections and electoral behavior. In: Sayari, Sabri, Esmer, Yılmaz R. (Eds.), Politics, Parties and Elections in Turkey. Lynne Rienner Publishers, Colorado, pp. 73-90.

Jackowicza, K., Kowalewskib, O., Kozowski, L., 2012. The influence of political factors on commercial banks in Central European countries. Journal of Financial Stability, http://dx.doi.org/10.1016/j.jfs.2012.08.001.

Julio, B., Yook, Y., 2012. Political uncertainty and corporate investment cycles. The Journal of Finance 67, 45-83.

Khwaja, A.I., Mian, A., 2005. Do lenders favor politically connected firms? Rent provision in an emerging financial market. Quarterly Journal of Economics 120, 1371-1411.

Körner, T., Schnabel, I., 2009. Public ownership of banks and economic growth. Economics of Transition 19, 407-441.

Laeven, L., Valencia, F., 2008. Systemic banking crises: a new database. IMF Working Paper, WP/08/224.

La Porta, R., Lopez-de-Silanes, F., Shleifer, A., 2002. Government ownership of banks. The Journal of Finance 57, 265-301.

Leuz, C., Oberholzer-Gee, F., 2006. Political relationships, global financing, and corporate transparency: evidence from Indonesia. Journal of Financial Economics 81, 411-439.

Levine, R., Loayza, N., Beck, T., 2000. Financial intermediation and growth: causality and causes. Journal of Monetary Economics 46, 31-77.

Levy-Yeyati, E., Micco, A., Panizza, U., 2007. A reappraisal of state-owned banks. Economia 7, 248-255.

McQuerry, E., 2001. Managed care for Brazil(tm)s banks. Federal Reserve Bank of Atlanta. Economic Review. 86, 27-44.

Micco, A., Panizza, U., 2006. Bank ownership and lending behavior. Economics Letters $93,248-254$.

Micco, A., Panizza, U., Ya nez, M., 2007. Bank ownership and performance: does politics matter? Journal of Banking and Finance 31, 219-241.

Önder, Z., Özyıldırım, S., 2010. Banks, regional development disparity and growth: evidence from Turkey. Cambridge Journal of Economics 34, 975-1000.

Önder, Z., Özyıldırım, S., 2011. Political connection, bank credits and growth: evidence from Turkey. World Economy 34, 1042-1065.

Rizzi, P., Dallara, A., 2011. The local impact of the crisis in a sustainable case. Working Paper.

Rodrik, D., 2005. Why we learn nothing from regressing economic growth on policies. Harvard University. Unpublished manuscript.

Sapienza, P., 2004. The effects of government ownership on bank lending. Journal of Financial Economics 72, 357-384.

Schuknecht, L., 1996. Political business cycles and fiscal policies in developing countries. KYKLOS 49, 155-170.

Steinherr, A., Tukel A., Ucer, M., 2004. The Turkish banking sector challenges and outlook in transition to EU Membership. EU - Turkey Working Papers, Center for European Policy Studies, Brussels, August.

Yaron, J., 2004. State-owned development finance institutions: background, political economy and performance assessment. Seminar Paper, Inter-American Development Bank, Washington, DC. 